\title{
Silicon Seed Priming Combined with Foliar Spray of Sulfur Regulates Photosynthetic and Antioxidant Systems to Confer Drought Tolerance in Maize (Zea mays L.)
}

\author{
Muhammad Farman $^{1} \cdot$ Fahim Nawaz ${ }^{1,2}$ (1) $\cdot$ Sadia Majeed $^{3} \cdot$ Hafiz Muhammad Rashad Javeed $^{4} \cdot$ Muhammad Ahsan $^{5} \cdot$ \\ Khawaja Shafique Ahmad ${ }^{6} \cdot$ Muhammad Aurangzaib $^{3} \cdot$ Muhammad Adnan Bukhari $^{3} \cdot$ Muhammad Asif Shehzad $^{1}$. \\ Muhammad Baqir Hussain ${ }^{7}$
}

Received: 12 September 2021 / Accepted: 21 October 2021 / Published online: 1 December 2021

(C) The Author(s) 2021

\begin{abstract}
The present study evaluated the effect of silicon ( $\mathrm{Si}$ ) seed priming and sulfur (S) foliar spray on drought tolerance of two contrasting maize hybrids viz. drought tolerant Hi-Corn 11 and susceptible P-1574. The maize seeds were primed with $(3 \mathrm{mM}$ $\mathrm{Na}_{2} \mathrm{SiO}_{3}$ ) or without $\mathrm{Si}$ (hydropriming) and later sown in pots filled with sandy loam soil. Drought stress (25-30\% water holding capacity or WHC) was initiated at cob development stage (V5) for two weeks, whereas the well-watered plants were grown at $65-70 \%$ WHC. On appearance of drought symptoms, foliar spray of S was done using $0.5 \%$ and $1.0 \%\left(\mathrm{NH}_{4}\right)_{2} \mathrm{SO}_{4}$, whereas water spray was used as a control. The drought-stressed plants were grown for further two weeks at 25-30\% WHC before the final harvest. The results showed a marked effect of Si seed priming and foliar S spray on biomass, physiological and enzymatic processes as well as macronutrient concentrations of maize. In comparison to control, the highest increase in leaf relative water content (25\%), chlorophyll a content $(56 \%)$, carotenoids $(26 \%)$, photosynthetic rate $(64 \%)$, stomatal conductance $(56 \%)$ and intercellular $\mathrm{CO}_{2}$ concentration (48\%) was observed by $\mathrm{Si}$ seed priming $+\mathrm{S}$ foliar spray $(\mathrm{Si}+\mathrm{S})$ under water deficit conditions. Also, $\mathrm{Si}+\mathrm{S}$ application stimulated the activity of catalase (45\%), guaiacol peroxidase (38\%) and superoxide dismutase (55\%), and improved NPK concentrations (40-63\%) under water limitations. Our results suggest that Si seed priming + foliar spray of S is more effective than the individual application of these nutrients to enhance drought tolerance in maize.
\end{abstract}

Keywords Silicon $\cdot$ Sulfur $\cdot$ Pigments $\cdot$ Gas exchange $\cdot$ Antioxidant enzymes $\cdot$ Macronutrients

Fahim Nawaz

fahim5382@gmail.com; fahim.nawaz@uni-hohenheim.de

1 Department of Agronomy, MNS University of Agriculture, Multan, Pakistan

2 Institute of Crop Science (340h), University of Hohenheim, 70599 Stuttgart, Germany

3 Department of Agronomy, Faculty of Agriculture \& Environmental Sciences, The Islamia University of Bahawalpur, Bahawalpur, Pakistan

4 Department of Environmental Sciences, COMSATS University Islamabad, Vehari Campus, Vehari 61100, Pakistan

5 Department of Horticultural Sciences, Faculty of Agriculture \& Environmental Sciences, The Islamia University of Bahawalpur, Bahawalpur, Pakistan

6 Department of Botany, University of Poonch, Rawalakot, Azad Jammu and Kashmir, Pakistan

7 Department of Soil and Environmental Sciences, MNS University of Agriculture, Multan, Pakistan

\section{Introduction}

Drought is one of the most destructive environmental stresses that cause significant economic losses to food crops [1]. Elevated temperature and the uncertainty of the global climate with reduced rainfall reliability are the major causes for the increased frequency of drought events around the world [2]. The damaging effects of drought are usually more evident within agriculture than that of other economically important sectors, resulting in soil degradation, reduced yields and crop failure [3]. Maize is an important food crop that feeds more than half of the global population [4]. However, drought considerably decreases maize yield and can cause up to 30-32\% losses of dry weight [5]. The water deficit stress has been shown to alter root system architecture, delay silk and tassel emergence, induce abnormal embryo formation and reduce the kernel numbers, which severely hampers the final kernel 
yield in maize $[6,7]$. Thus, there is a need to develop approaches directed towards increasing drought resilience in maize to avoid yield losses.

Numerous practices such as the breeding of tolerant varieties, characterization of drought-responsive genes/ QTLs and genomic approaches are being followed to cope with drought stress [8]. Though these approaches are innovative and sophisticated, they require technical skills, huge investments and are often very time consuming. On the other hand, the use of shot-gun, inexpensive approaches such as seed priming and the foliar application of plant growth regulators and mineral nutrients has become increasingly popular in the recent past $[9,10]$. Seed priming is an effective agro-technical approach that minimizes the risk of poor germination and impaired seedling establishment under harsh conditions [11]. Also, priming agents may induce some specific and non-specific transcriptional modifications that enable plants to survive extreme conditions at later stages of growth [12]. Marthandan et al. [13] suggested that seed priming brings several cellular changes including the activation of phospholipids and sterols, synthesis of proteins and upregulation of antioxidants, all of which contribute to increase tolerance against drought stress. Similarly, the foliar spray of mineral nutrients ensures the direct application of fertilizers to the site of demand; thereby facilitating the rapid absorption of nutrients by leaf tissues [14, 15]. This method of nutrient supply is particularly important under dry, arid conditions when the transport of mineral elements by roots is limited [16].

Silicon ( $\mathrm{Si}$ ) is a naturally occurring beneficial element and has been extensively used as a potential plant growth promoter in recent years $[17,18]$. Provision of Si improves plant water uptake and water use efficiency under water deficit conditions [19]. Avila et al. [20] reported that $\mathrm{Si}$ supply enhances the hydraulic activity of roots by increasing the expression of plasma membrane intrinsic protein (PIP) aquaporins in water stressed sorghum seedlings. In addition, it modulates ion homeostasis and reduces lipid peroxidation by reactive oxygen species (ROS) under drought stress [21]. Improved osmotic adjustment, decreased transpiration rate and increased structural stability of cellular membranes are also attributed to the availability of Si to plants exposed to dry conditions [22, 23]. More recently, Si nanoparticles have been reported to increase water retention of soils that may help to improve plant growth and development under stress conditions [24, 25]. Akin to $\mathrm{Si}$, sulfur (S) is a key nutrient that is well documented for its beneficial role in plants [26, 27]. It is taken up by plants as sulfate $\left(\mathrm{SO}_{4}{ }^{2-}\right)$ and is the only macronutrient present in the xylem sap of water deficit maize plants [28]. Besides increasing biosynthesis of chlorophyll and proteins, S availability influences cellular metabolic reactions to regulate photosynthetic apparatus and antioxidant machinery in maize under drought stress [29].

In a recent study, Si nutrition was reported to increase the uptake of $\mathrm{S}$ in tomato exposed to osmotic stress conditions [30] while it decreased S accumulation in shoots of barley under $\mathrm{S}$ deficiency [31]. However, the understanding of the effects of combined application of $\mathrm{Si}$ and $\mathrm{S}$ on physiological and metabolic processes of plants under drought is limited. In this study, we tried to partially fill this knowledge gap by investigating whether, and to what extent, $\mathrm{Si}+\mathrm{S}$ supply increases drought tolerance in maize. We hypothesized that $\mathrm{Si}$ seed priming in combination with $\mathrm{S}$ foliar spray regulates physiological processes and stimulates stress metabolites to increase drought tolerance in maize.

\section{Material and Methods}

\subsection{Experimental Conditions and Treatments}

A pot experiment was conducted in a semi-controlled green house (12-14 h sunshine, average day/night temperature 25/ $18{ }^{\circ} \mathrm{C}$, relative humidity $60-65 \%$ ) in triplicated completely randomized design. Two contrasting maize hybrids viz. HiCorn11 (drought tolerant, [32]) and P-1574 (drought susceptible, [33]) were randomly collected from ICI and Kanzo Pakistan Pvt. Limited, respectively. All maize seeds were initially disinfected using recommended doses of an insecticide (Imidacloprid) and a fungicide (Topsin-M-70-WP). Sandy loam soil with $\mathrm{pH} 8.0,0.57 \%$ organic matter, $\mathrm{N}$ at $96 \mathrm{mg} \mathrm{kg}^{-1}$, P at $110 \mathrm{mg} \mathrm{kg}^{-1}$ and $\mathrm{K}$ at $4.30 \mathrm{mg} \mathrm{kg}^{-1}$ measured following Jackson and Barak [34] was used for the research study. The experiment comprised of 72 earthen clay pots (diameter $28.5 \mathrm{~cm}$, depth $55 \mathrm{~cm}$ ) and recommended application rates for inorganic fertilizers such as urea $\left(120 \mathrm{~kg} \mathrm{ha}^{-1}, 0.60 \mathrm{~g}\right.$ per $\mathrm{kg}$ soil in pot), diammonium phosphate $\left(80 \mathrm{~kg} \mathrm{ha}^{-1}, 0.96 \mathrm{~g}\right.$ per kg soil in pot) and potassium oxide phosphate $\left(80 \mathrm{~kg} \mathrm{ha}^{-1}\right.$, $0.96 \mathrm{~g}$ per $\mathrm{kg}$ soil in pot) were mixed in the soil before filling each pot with $12 \mathrm{~kg}$ soil. The half of the total urea was mixed in the soil before pot filling, whereas the remaining half was applied as a nutrient solution three weeks after sowing (V3, three leaf stage).

Maize seeds were primed with $3 \mathrm{mM} \mathrm{Si}$, reported as the most effective dose for Si seed priming by Bukhari et al. [35], for $12 \mathrm{~h}$ using sodium metasilicate $\left(\mathrm{Na}_{2} \mathrm{SiO}_{3}, \mathrm{pH} 11.2\right.$, $0.6375 \mathrm{~g} \mathrm{~L}^{-1}$, Sigma-Aldrich) and later shade dried. Initially, five seeds were sown in each pot, however, after emergence they were later thinned to only one healthy plant in each pot. The experiment comprised 72 pots: two watering regimes (well-watered and drought), two hybrids (Hi-Corn 11 and P-1574), and six treatments (control, Si seed priming, foliar spray of $0.5 \%$ and $1 \% \mathrm{~S}$ spray and Si seed priming + foliar 
spray of $0.5 \%$ and $1 \% \mathrm{~S}$ spray) each replicated three times. The soil moisture content was checked by finger test method and water holding capacity (WHC) was computed accordingly [36]. All plants were well-watered and maintained at 65$70 \%$ WHC for first four weeks and then drought stress was imposed in one set of pots at cob development stage (V5, 28 days after sowing), and their water content was gradually decreased to $25-30 \%$ WHC. The soil moisture levels were monitored with a moisture meter (ML-3 Theta Probe, UK), and the pots were weighed daily to maintain the moisture levels. Drought stress (25-30\% WHC) was continued for another two weeks and on appearance of drought symptoms, foliar application of S was done at VT stage (before flowering, 49 days after sowing) using ammonium sulfate $\left[\left(\mathrm{NH}_{4}\right)_{2} \mathrm{SO}_{4}\right.$, purity $\geq 99.0 \%$, Sigma-Aldrich, USA)]. Two S doses i.e. $0.5 \%$ and $1 \%$ (including $0.1 \%$ Tween-20 as a surfactant) were used for foliar spray and the spray treatments were repeated after one week. The plants were maintained at water stress levels (25-30\% WHC) for another two weeks after first spray and the leaf samples were collected to determine various physiological and biochemical attributes. Later, the plants were manually harvested and the harvested plant material was used to record growth attributes and determine NPK concentrations.

\subsection{Determination of Pigments and Water Status}

The leaf chlorophyll content was measured using Arnon [37] method. At first, $1 \mathrm{~g}$ fresh leaves were homogenized and grinded in ice-cold pestle and mortar using $80 \%$ acetone solution. Prepared samples were centrifuged for $15 \mathrm{~min}$ at $30000 \mathrm{rpm}$. Then supernatant solution was poured into colorimeter tube and chlorophyll content was measured at optical density $(645 \mathrm{~nm}$ and $663 \mathrm{~nm}$ ) by using (UV 240) shimadzu-35 double beam spectrophotometer. Pigments (Chlorophyll a, b and carotenoids) were measured using following formulae.

$$
\begin{aligned}
& \mathrm{Chl}_{\mathrm{a}}\left(\mathrm{mg} \mathrm{g}^{-1} \mathrm{FW}\right)=[12.7(\text { OD663 })-2.69(\mathrm{OD} 645)] \times \mathrm{V} / 1000 \times \mathrm{W} \\
& \mathrm{Chl}_{\mathrm{b}}\left(\mathrm{mg} \mathrm{g}^{-1} \mathrm{FW}\right)=[22.9(\mathrm{OD} 645)-4.68(\mathrm{OD} 663)] \times \mathrm{V} / 1000 \times \mathrm{W} \\
& \mathrm{CAR}\left(\mu \mathrm{g} \mathrm{g}^{-1} \mathrm{FW}\right)=\mathrm{A}_{\mathrm{car}} / \mathrm{E}_{\max } 100
\end{aligned}
$$

Where $V$ is the volume of sample extract and $W$ is the weight of the sample and Acar $=(O D 480)+0.114$ (OD663)-0.638 (OD645); $\operatorname{Emax}^{100} \mathrm{~cm}=2500$.

Fresh leaves $(0.5 \mathrm{~g})$ were weighed $(\mathrm{FW})$ and then dipped into distilled water for $24 \mathrm{~h}$ and afterwards, the wet leaves were wiped with tissue paper and weighed again i.e. turgid weight. The same leaves were kept in an oven at $65{ }^{\circ} \mathrm{C}$ for $72 \mathrm{~h}$ for dry weight to estimate leaf relative water content (RWC) as reported by Mayak et al. [38].

\subsection{Measurement of Gaseous Exchange}

The leaf stomatal conductance $\left(g_{s}\right)$, photosynthetic rate $(A)$ and rate of transpiration $(E)$ were estimated using CIRAS-3 (PP systems, Amesbury, U.S.A) open flow portable gaseous exchange. All the measurements were taken early in the morning from 8:00 am to 10:00 AM. Following adjustments i.e., chamber adjustment at $\left(100 \mathrm{~mL} \mathrm{m^{-1 }} \mathrm{mL}\right.$ airflow rate), photosynthetic density of photon at $\left(1200 \mu \mathrm{mol} \mathrm{m}^{-2} \mathrm{~s}^{-1}\right)$, concentration rate of $\mathrm{CO}_{2}$ at $\left(390 \pm 5 \mu \mathrm{mol} \mathrm{mol}^{-1}\right)$ and pressure of atmosphere at $(99.9 \mathrm{kpa})$ were executed for recording observations [16].

\subsection{Assay of Antioxidant Enzymes}

Leaf samples $(0.2 \mathrm{~g})$ were taken in pestle-mortar and homogenized (1:5) using $\mathrm{Na}_{2} \mathrm{HPO}_{4}(50 \mathrm{mM})$, sodium chloride $(1 \mathrm{M})$ with $\mathrm{pH} 7.5$, EDTA $(1 \mathrm{mM})$ and polyvinylpyrrolidone (1\%). These samples were taken in falcon tubes $(15 \mathrm{~mL})$ and centrifuged at $20000 \mathrm{rpm}$ for $15 \mathrm{~min}$ at $4{ }^{\circ} \mathrm{C}$. Analyses of antioxidants were carried out by taking supernatant enzymes extract (EE) from centrifuged falcon tubes.

To measure the catalase (CAT) activity, reaction mixture (RM) was prepared by adding $\left(30 \mathrm{mM} \mathrm{H}_{2} \mathrm{O}_{2}\right.$ and $50 \mathrm{~mm} \mathrm{~K}-\mathrm{P}$ buffer of pH 7.5). $200 \mu \mathrm{L}$ EE was taken from falcon tubes by micro pipette and added into $1.8 \mathrm{~mL} \mathrm{RM}$ in sample holder cuvette. Cuvette was placed into spectrophotometer and CAT readings were noted at optical density $(240 \mathrm{~nm})$ by using same RM as a blank sample [39].

Urbanek et al. [40] was followed to measure the peroxidase (GPX) enzyme activity. EE ( $25 \mu \mathrm{l})$ was added with $2 \mathrm{~mL} \mathrm{RM}$ which was prepared by blending following chemicals (50 mM K-P buffer of $\mathrm{pH} 7.5,20 \mathrm{mM} \mathrm{H} \mathrm{H}_{2}$ and $20 \mathrm{mM}$ guaiacol) in falcon tubes and incubated for $10 \mathrm{~min} .1 \mathrm{~mL}$ mixture was taken from falcon tubes and mixed with $0.5 \mathrm{~mL}$ of $5 \% \mathrm{H}_{2} \mathrm{SO}_{4}$ solution in cuvette. This cuvette was kept into spectrophotometer and at optical density $(480 \mathrm{~nm})$ readings were noted after one minute.

Van Rossum et al. [41] was used to measure the activity of superoxide dismutase (SOD) enzyme. According to this method $50 \mu \mathrm{EE}$ extract was added with $1 \mathrm{~mL}$ of each following chemicals: $130 \mathrm{mM}$ L-methionine, $750 \mu \mathrm{M}$ NBT, $1000 \mu \mathrm{M}$ EDTA, $20 \mu \mathrm{M}$ Riboflavin and $100 \mathrm{mM}$ K-P buffer of $\mathrm{pH} 7.5$ in falcon tubes. Than the tubes were kept into elimination chamber under the lamp (30-W) for 10 min until blue color formazan produced. To check the NBT's photo-reduction absorbance was increased to $560 \mathrm{~nm}$. RM without EE was used as control in spectrophotometer but it was kept in dark for $10 \mathrm{~min}$.

\subsection{Estimation of Shoot NPK Concentrations}

For nutrients (NPK) analysis, oven dried leaves $(0.5 \mathrm{~g})$ were ground in Willey mill and homogenized. Later, homogenized 
dried samples were digested in BD50 digestion block (SEAL Analytical, Malaysia) using $5 \mathrm{~mL}$ of $\mathrm{H}_{2} \mathrm{SO}_{4}$ [42]. After digestion, $2 \mathrm{~mL}$ of $\mathrm{H}_{2} \mathrm{O}_{2}$ was taken by micro pipette and poured into tubes. A digestion block fitted with tubes was used to heat the samples at $350{ }^{\circ} \mathrm{C}$ for three hours until fumes were produced continuously. Then extract was withdrawn into volumetric flask $(50 \mathrm{~mL})$ and volume was maintained by adding distilled water. What-man 40 filter paper was used to filter the extract and $\mathrm{N}$ concentrations were measured by Kjeldhal method. $\mathrm{P}$ and $\mathrm{K}$ contents were measured by flame photometer (Sherwood M410, UK) using vanadium molybdate yellow colorimetric method.

\subsection{Statistical Analysis}

The statistical analysis of the data was done on Statistix (Version 8.1) and Fisher's three-way ANOVA (Analysis of Variance) was employed. The treatment means were compared using Tukey's Honest Significant Difference (HSD) test with $5 \%$ probability.

\section{Results}

\subsection{Biomass Production}

Drought stress considerably ( $p<0.001$ ) decreased the growth of maize hybrids and caused a significant reduction of $21 \%$, $61 \%, 48 \%, 41 \%$ and $42 \%$ in shoot length (SL), shoot fresh weight (SFW), root fresh weight (RFW), shoot dry weight (SDW) and root dry weight (RDW), respectively (Table 1). Conversely, the water stressed maize plants exhibited significantly higher (10\%) root length (RL) than that of well-watered plants. Also, the drought tolerant hybrid Hi-Corn 11 maintained markedly higher SL (8\%), SFW (11\%), RFW (6\%), and SDW (12\%) than that of sensitive P-1574 (Table 1). Among various treatments, the highest increase in growth attributes was recorded by $\mathrm{Si}$ seed priming combined with $0.5 \% \mathrm{~S}$ foliar spray $(\mathrm{Si}+\mathrm{S} 1)$. In comparison to control, the application of $\mathrm{Si}+\mathrm{S} 1$ significantly increased the SL, RL, SFW, RFW, SDW and RDW by $26 \%, 16 \%, 37 \%, 27 \%$, $35 \%$ and $33 \%$, respectively. A significant interaction (D x H $\mathrm{x} \mathrm{T}$ ) for RL and SFW showed that $\mathrm{Si}+\mathrm{S} 1$ resulted in the highest RL in P-1574, whereas Si seed priming combined with $1 \% \mathrm{~S}$ spray $(\mathrm{Si}+\mathrm{S} 2)$ gave the highest SFW in the same hybrid under water deficit conditions (Table 1).

\subsection{Pigments and Leaf Relative Water Content}

In comparison to well-watered conditions, drought stress significantly $(p<0.001)$ reduced the leaf chlorophyll a $\left(\mathrm{Chl}_{\mathrm{a}}\right)$, chlorophyll b $\left(\mathrm{Chl}_{\mathrm{b}}\right)$ and carotenoids (CAR) content by 13,10 and $17 \%$, respectively (data presented as Suppl. Table S1).
While the maize hybrids did not exhibit significant difference for CAR, Hi-Corn 11 maintained considerably higher $(6 \%)$ $\mathrm{Chl}_{\mathrm{a}}$ and $\mathrm{Chl}_{\mathrm{b}}$ than $\mathrm{P}-1574$. The leaf photosynthetic pigments were significantly higher in plants raised from Si primed seeds or foliar applied with S compared with the control (Fig. 1a, b and c). The highest increase in leaf $\mathrm{Chl}_{\mathrm{a}}(56 \%)$ was observed by $\mathrm{Si}+\mathrm{S} 1$ ( $\mathrm{Si}$ seed priming $+0.5 \% \mathrm{~S}$ spray) statistically related to $\mathrm{Si}+\mathrm{S} 2$ ( $\mathrm{Si}$ seed priming $+1 \% \mathrm{~S}$ spray), which gave the highest increment in $\mathrm{Chl}_{\mathrm{b}}(56 \%)$ and CAR $(26 \%)$ content under water limitations (Fig. 1a, b and c).

Drought induced decrease in leaf relative water content (RWC) was significantly higher (20\%) in water-stressed than that of well-watered plants (data presented as Suppl. Table S1). Treatment of maize seeds with Si or foliar application of S markedly improved the leaf RWC under drought stress conditions, whereas no significant increase was observed under well-watered conditions (Fig. 1d). Compared with the control, Si seed priming increased the leaf RWC by $14 \%$, statistically similar to $0.5 \%$ and $1 \% \mathrm{~S}$ spray treatments. However, a much higher increase was observed by the combined Si seed priming and S spray treatments, which improved the leaf RWC by $22 \%(\mathrm{Si}+\mathrm{S} 1)$ and $25 \%(\mathrm{Si}+\mathrm{S} 2)$ under water deficit conditions (Fig. 1d).

\subsection{Leaf Gas Exchange Characteristics}

A marked effect $(p<0.001)$ of water limitations was observed on the gas exchange characteristics of maize plants, which showed significantly lower photosynthetic rate $(A$, $43 \%)$, transpiration rate $(E, 39 \%)$, stomatal conductance $\left(g_{s}\right.$, $54 \%)$, and intercellular $\mathrm{CO}_{2}$ concentration $\left(C_{i}, 35 \%\right)$ under drought stress compared with the well-watered conditions (data presented as Suppl. Table S1). No significant differences were observed between maize hybrids for gas exchange attributes except $\mathrm{Ci}$, which was found higher (5\%) in P-1574 than Hi-Corn 11. The Si seed priming combined with $1 \% \mathrm{~S}(\mathrm{Si}+$ $\mathrm{S} 2)$ resulted in the highest increase in $A(64 \%)$ and $g_{s}(56 \%)$, whereas $\mathrm{Si}+\mathrm{S} 1$ ( $\mathrm{Si}$ seed priming $+0.5 \% \mathrm{~S}$ spray) gave the highest $E(70 \%)$ and $C_{i}(48 \%)$ statistically related to $\mathrm{Si}+\mathrm{S} 2$ with respect to control under water deficit conditions (Fig. 2a, b, c and d).

\subsection{Antioxidant Enzymes}

The enzymatic activity of different antioxidant enzymes viz. catalase (CAT), guaiacol peroxidase (GPX) and superoxide dismutase (SOD) was markedly stimulated by water limitations (data presented as Suppl. Table S1). The exposure to drought significantly increased the antioxidant activity of CAT $(62 \%)$, GPX $(38 \%)$ and SOD $(73 \%)$ in water-stressed than the well-watered plants. While no marked effect of Si seed priming and $\mathrm{S}$ foliar spray treatments was observed on the activity of antioxidant enzymes under well-watered 
Table 1 Effect of silicon seed priming combined with sulfur foliar spray on shoot length (SL, $\mathrm{cm}$ ), root length (RL, $\mathrm{cm}$ ), shoot fresh weight (SFW, g), root fresh weight (RFW, g), shoot dry weight (SDW, g), and root dry weight (RDW, g) of a drought tolerant (Hi-Corn 11) and sensitive (P-1574) maize (Zea mays L.) hybrid under wellwatered and drought stress conditions

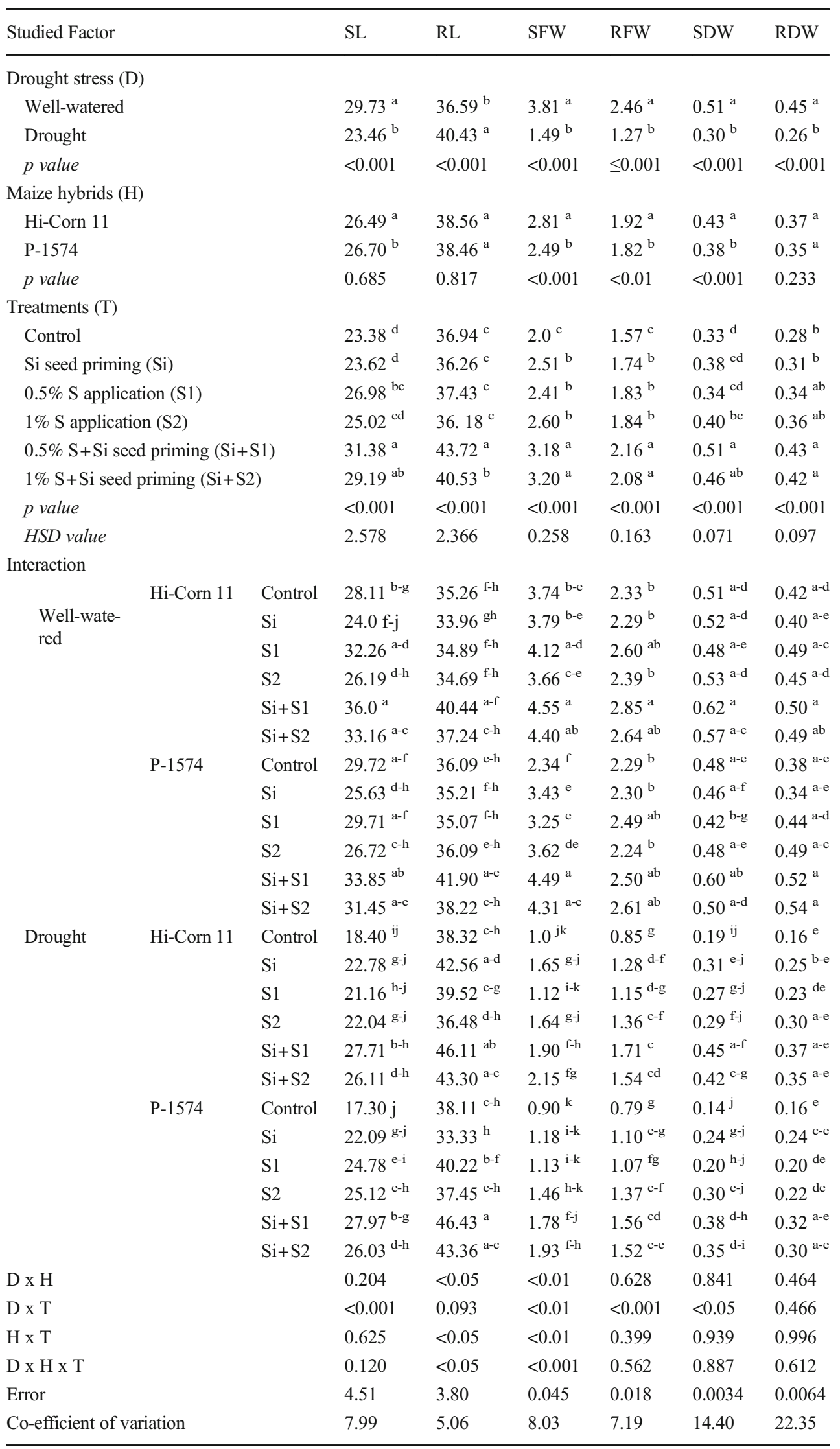

p value: probability value; $H S D$ value: Honest significant difference value 
conditions, a considerable $(p<0.001)$ increase in the enzymatic activity was recorded under water deficit conditions (Fig. 3a, b and c). Maize plants raised from Si primed seeds and foliar applied with $0.5 \% \mathrm{~S}(\mathrm{Si}+\mathrm{S} 1)$ exhibited the highest CAT $(45 \%)$, GPX (38\%) and SOD (55\%) activity in comparison to control under drought stress conditions. The individual application of Si seed priming or foliar spray of S $(0.5 \%$ and $1 \%)$ also increased the CAT, GPX and SOD activity by $12-33 \%, 8-29 \%$ and $16-49 \%$, respectively with respect to control under water limitations (Fig. 3a, b and c).

a.

$\square$ Hi-Corn $11 \quad \square$ P-1574

p-value: 0.049

HSD value: 0.217

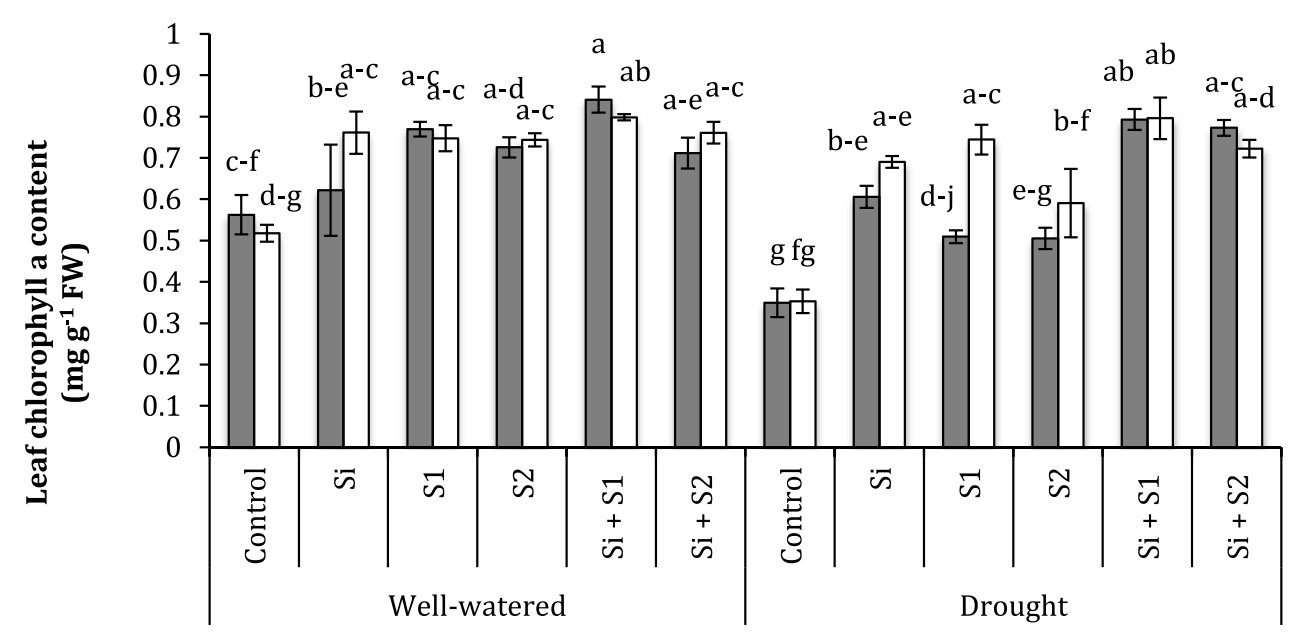

Treatments

b.

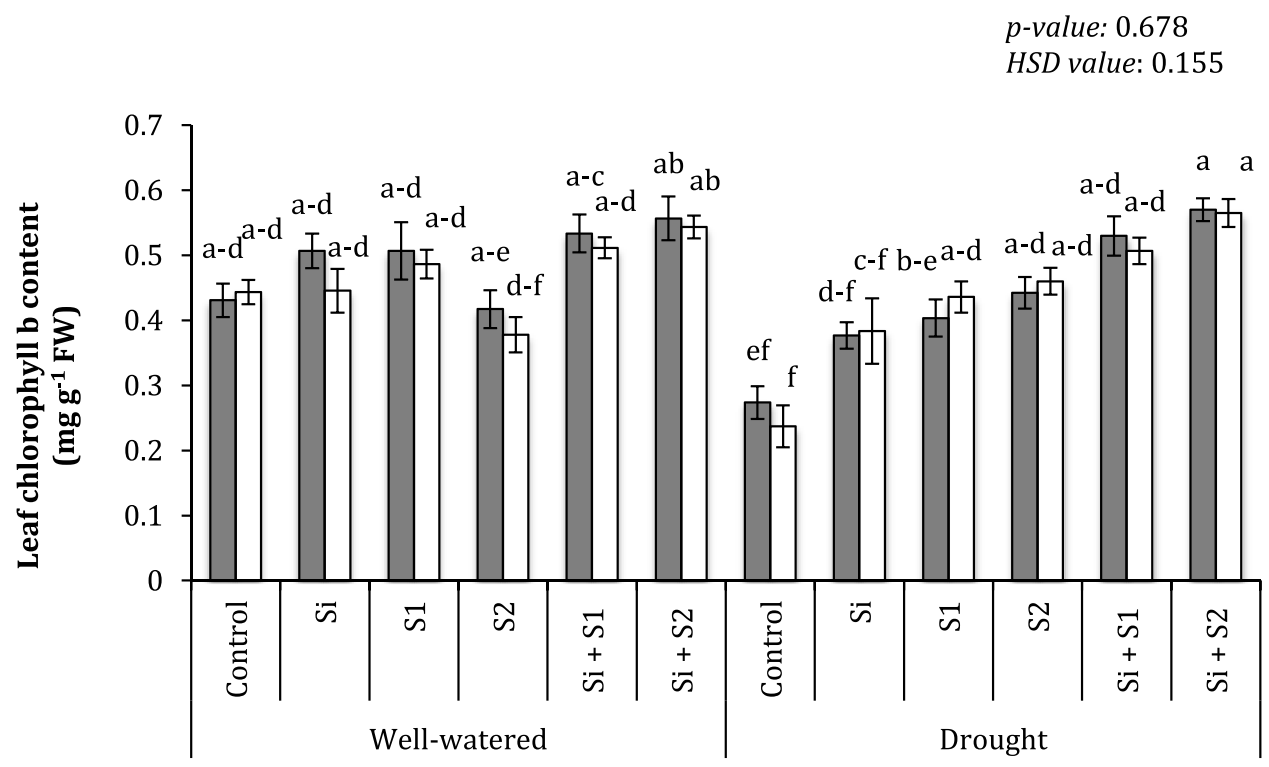

Treatments

Fig. 1 Effects of Si seed priming and foliar spray of $\mathrm{S}\left(\mathrm{S}_{1}: 0.5 \%, \mathrm{~S}_{2}: 1 \%\right)$ on (a) chlorophyll a $\left(\mathrm{Chl}_{\mathrm{a}}\right)$, (b) chlorophyll b $\left(\mathrm{Chl}_{\mathrm{b}}\right)$, (c) carotenoids (CAR) and (d) relative water content (RWC) content of well-watered and drought stressed maize seedlings. The error bars represent variability among different treatment means and were calculated by dividing standard deviation with the square root of number of replicates $(\mathrm{n}=3)$. Different alphabets show significant differences $(p \leq 0.05)$ amongst various treatments, according to Tukey's HSD test 
c.

p-value: 0.189

HSD value: 0.171

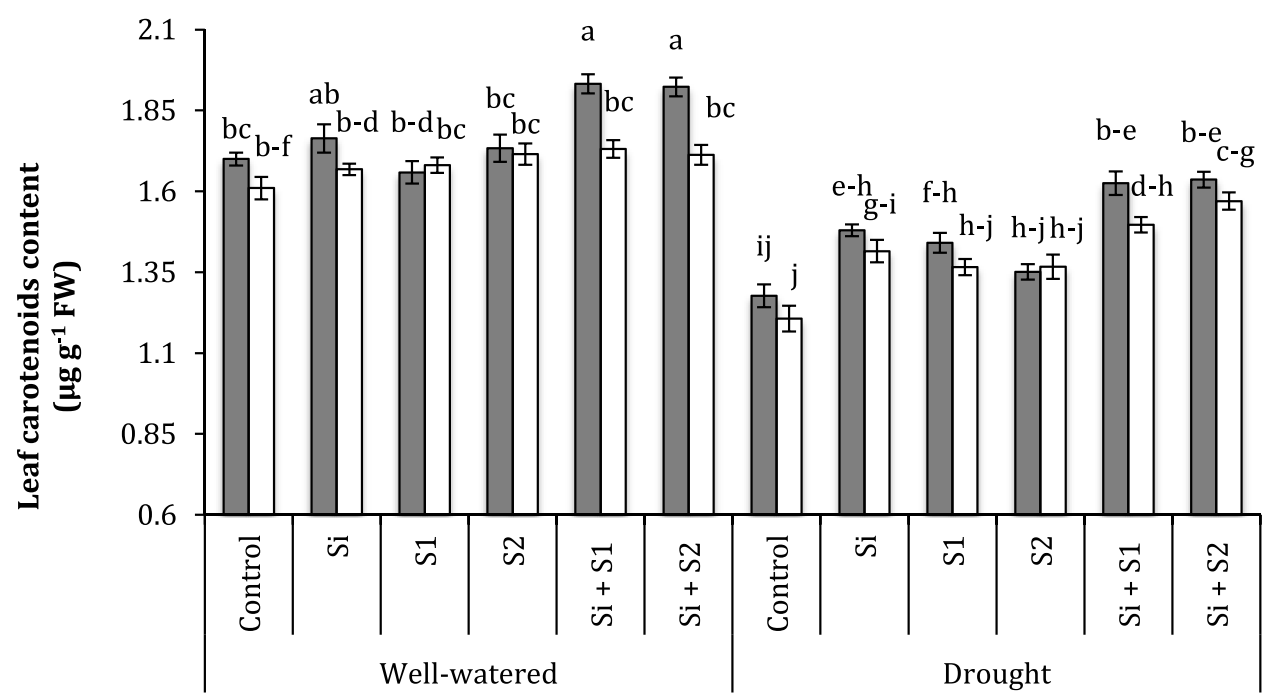

Treatments

d.

Fig. 1 (continued)

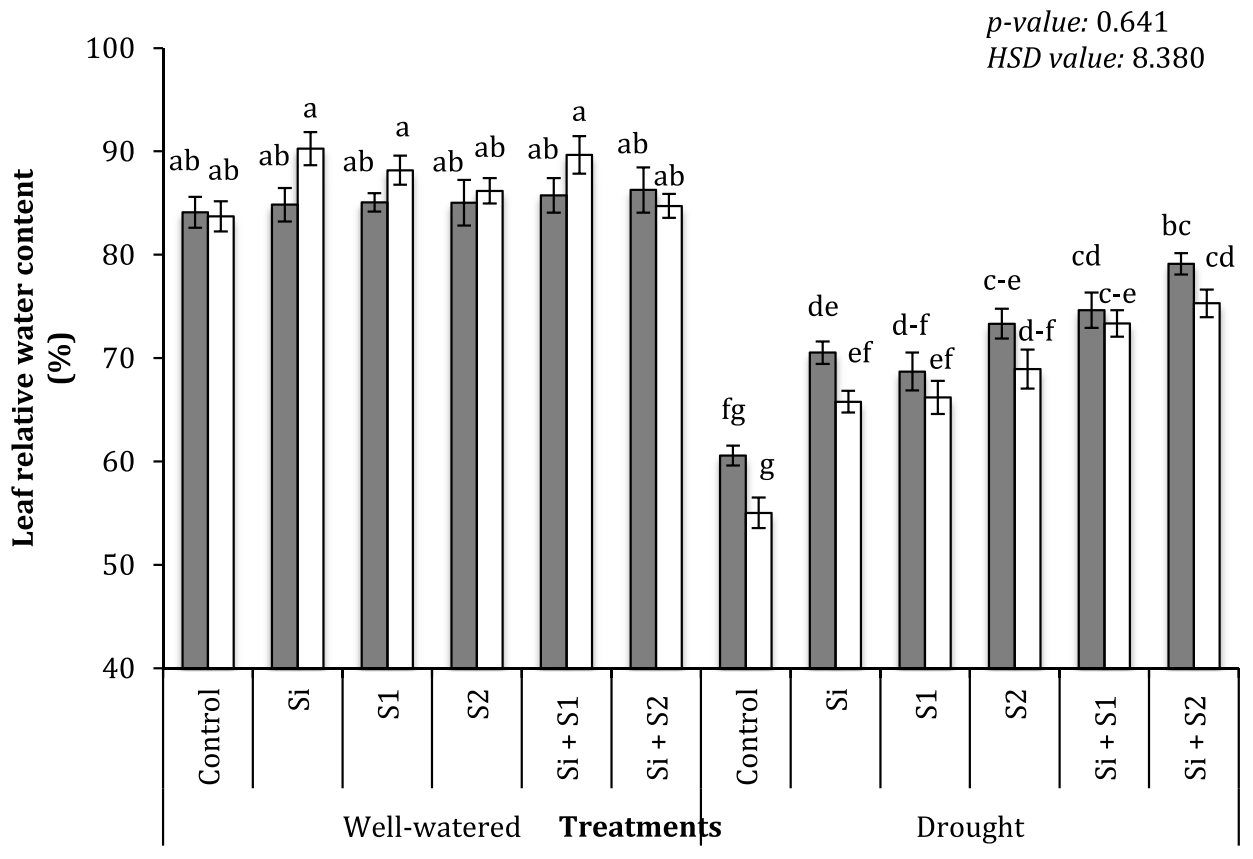

\subsection{Shoot NPK Content}

Drought stress significantly ( $p<0.001)$ decreased the shoot nitrogen $(\mathrm{N})$, phosphorus $(\mathrm{P})$ and potassium $(\mathrm{K})$ concentrations by $28 \%, 38 \%$ and $26 \%$, respectively in comparison to well-watered conditions (data presented as Suppl. Table S1). Interestingly, maize hybrid P-1574 exhibited significantly higher $\mathrm{N}, \mathrm{P}$ and $\mathrm{K}$ concentrations in comparison to Hicorn-11 under drought stress conditions (Fig. $4 \mathrm{a}, \mathrm{b}$ and $\mathrm{c}$ ). The individual or combined Si seed priming and $\mathrm{S}$ foliar spray markedly $(p<0.001)$ improved the $\mathrm{N}, \mathrm{P}$ and $\mathrm{K}$ accumulation in water stressed maize plants. In comparison to control, the highest increase in $\mathrm{N}(42.51 \%), \mathrm{P}(63 \%)$ and $\mathrm{K}(39.39 \%)$ concentrations was observed in plants treated with $\mathrm{Si}+\mathrm{S} 1$ under water deficit conditions (Fig. 4a, b and c). 


\section{Discussion}

The increasing evidence during the last decade suggests the beneficial effects of Si nutrition in alleviating the damaging effects of biotic and abiotic stresses in plants [30, 43]. It is well established that Si modulates the absorption of minerals, improves photosynthetic performance and regulates antioxidant systems, all of which contribute to increased tolerance against environmental stresses including drought $[9,44]$. However, limited literature is available on interactions of $\mathrm{Si}$ with essential plant nutrients like S. Some recent studies indicate that Si application enhanced the uptake of S that helped to

a.

$\square$ Hi-Corn $11 \quad \square \mathrm{P}-1574$

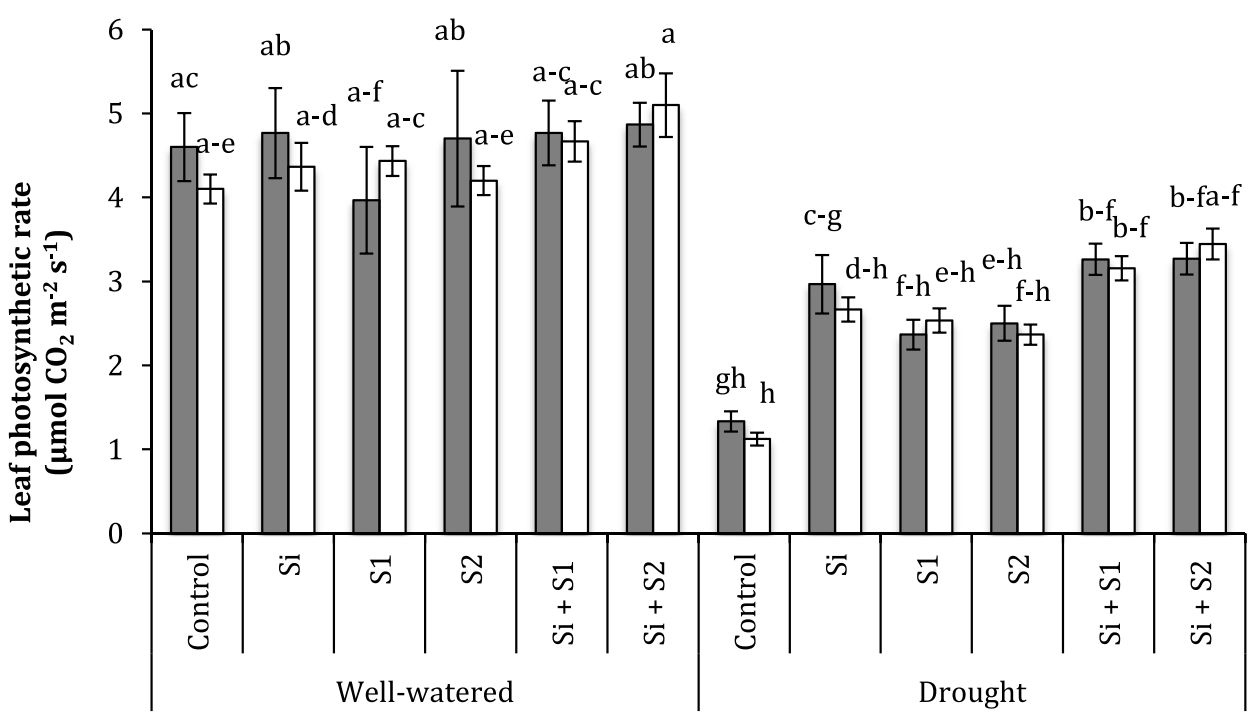

p-value: 0.045

HSD value: 1.715

Treatments

b.

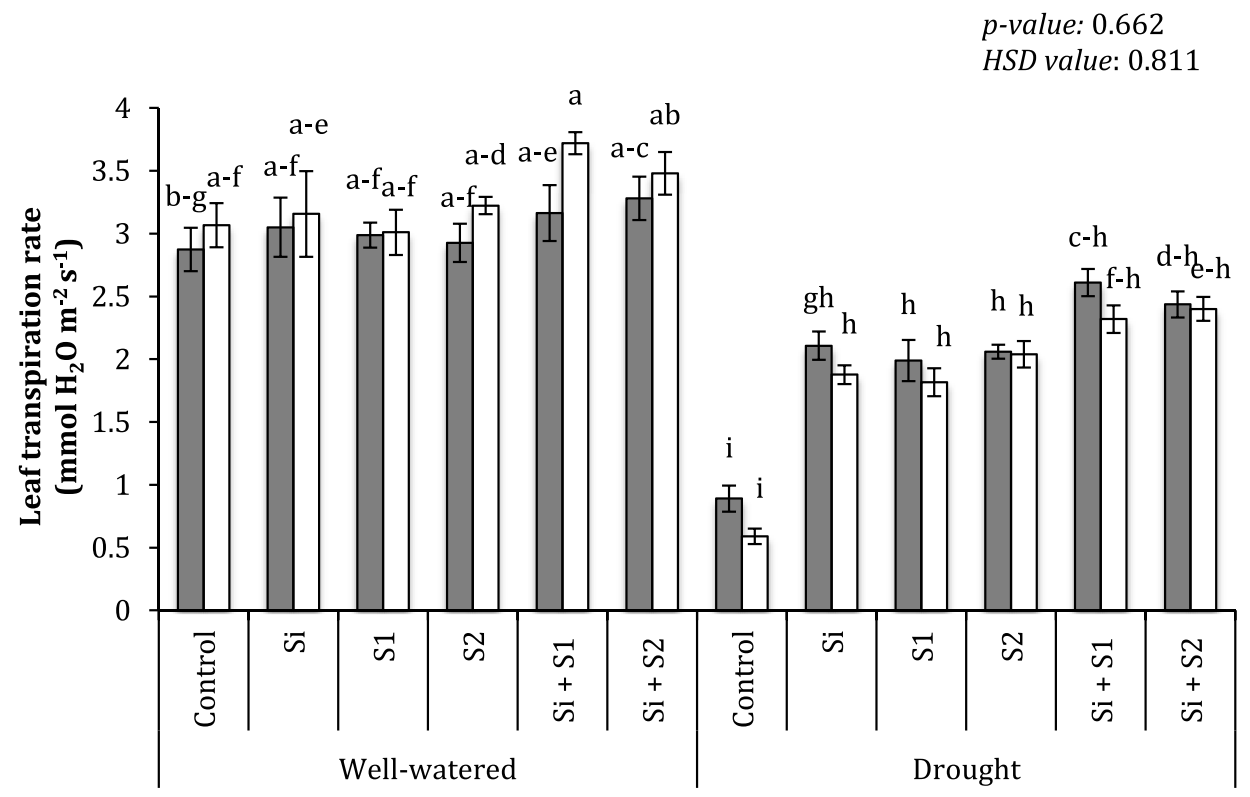

Treatments

Fig. 2 Effects of Si seed priming and foliar spray of $\mathrm{S}\left(\mathrm{S}_{1}: 0.5 \%, \mathrm{~S}_{2}: 1 \%\right)$ on (a) photosynthetic rate $(A)$, (b) transpiration rate $(E)$ and (c) stomatal conductance $\left(g_{s}\right)$ of well-watered and drought stressed maize seedlings. The error bars represent variability among different treatment means and were calculated by dividing standard deviation with the square root of number of replicates $(n=3)$. Different alphabets show significant differences $(p \leq 0.05)$ amongst various treatments, according to Tukey's HSD test 
c.

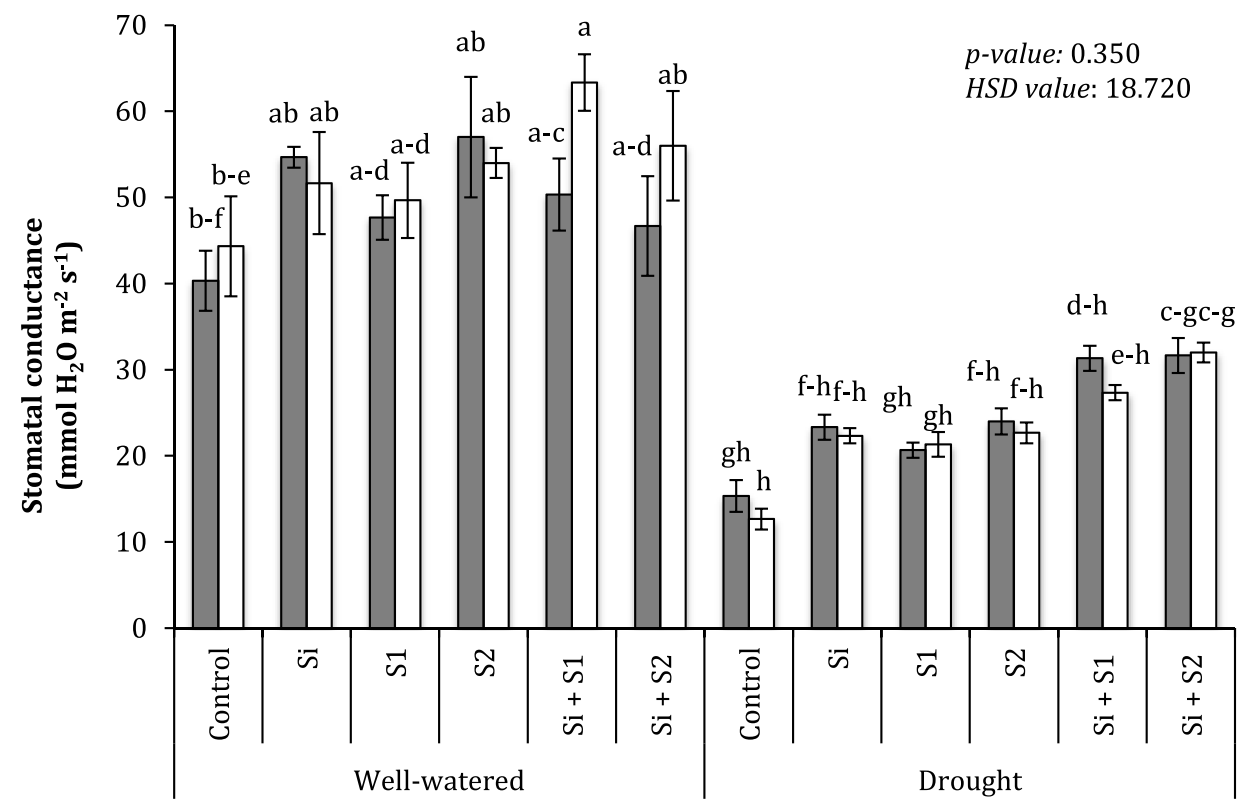

Treatments

d.

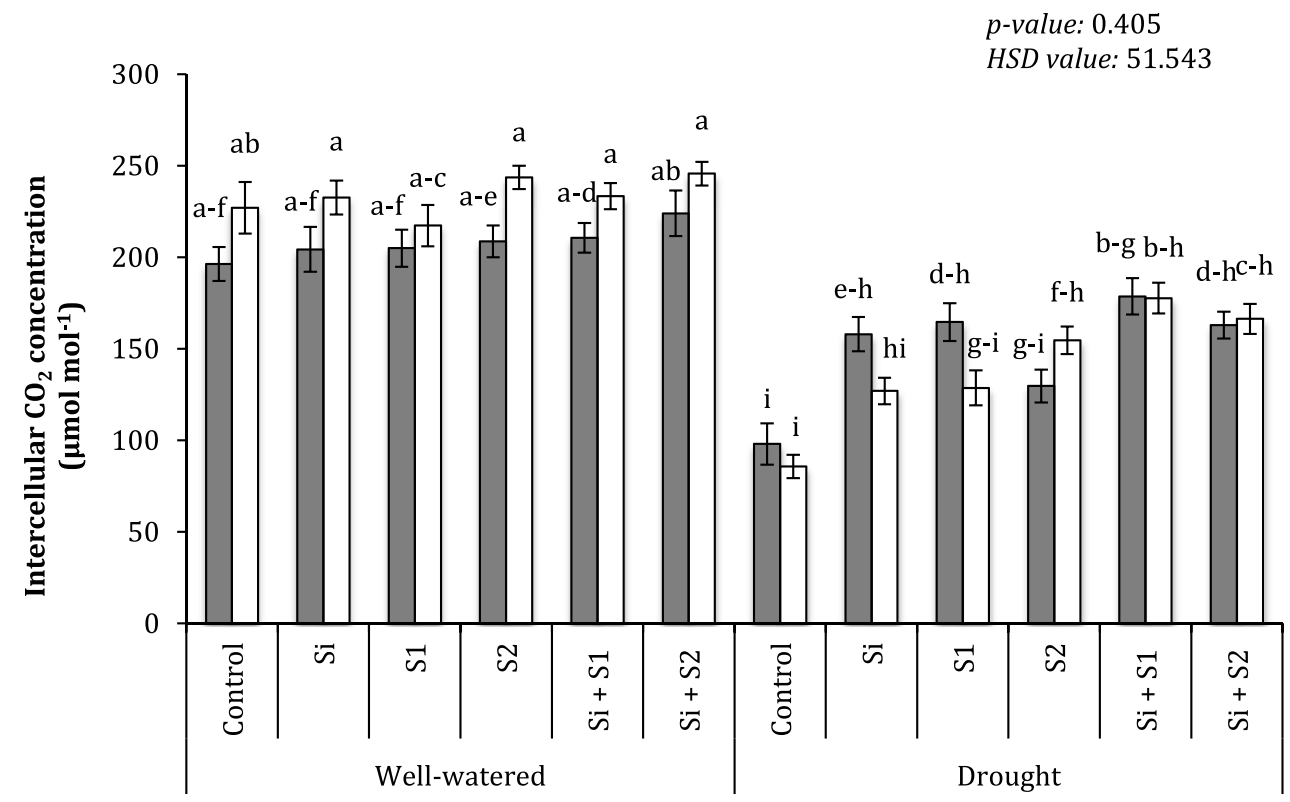

Treatments

Fig. 2 (continued)

balance the redox homeostasis in drought tolerant tomato cultivars [30]. Conversely, Buchelt et al. [45] observed no significant effects of Si supply on S accumulation in forage crops, whereas Réthoré et al. [46] reported that the addition of Si reduces $\mathrm{S}$ accumulation in rice. Interestingly, none of the previous studies investigated the combined effects of $\mathrm{Si}$ and $\mathrm{S}$ application under water limitations. Since $\mathrm{S}$ is the fourth major nutrient applied to plants externally and is involved in a series of regulatory mechanisms responsible for increased drought tolerance in plants [47], the present study elucidated the individual and combined effects of Si and S supply on physiological and enzymatic processes of two contrasting maize hybrids exposed to drought stress. Our results show the differential response of maize hybrids to exogenous $\mathrm{Si}$ and $\mathrm{S}$ application under drought stress. While the drought tolerant hybrid HiCorn 11 maintained higher biomass (Table 1), photosynthetic 
pigments (Fig. 1) and shoot NPK concentrations (Fig. 4), the sensitive hybrid P-1574 displayed an improvement in photosynthetic performance (Fig. 2) and activities of antioxidant enzymes (Fig. 3) by the combined Si and S supply under water deficit conditions.
The decrease in biomass is one of the major consequences of drought that severely affects the crop productivity leading to substantial yield losses [7]. In the present study, a marked decline in maize growth attributes was observed under water limitations. However, pre-treatment of seeds with $\mathrm{Si}$ and foliar

a.

$\square$ Hi-Corn $11 \square$ P-1574 p-value: 0.306

HSD value: 36.544

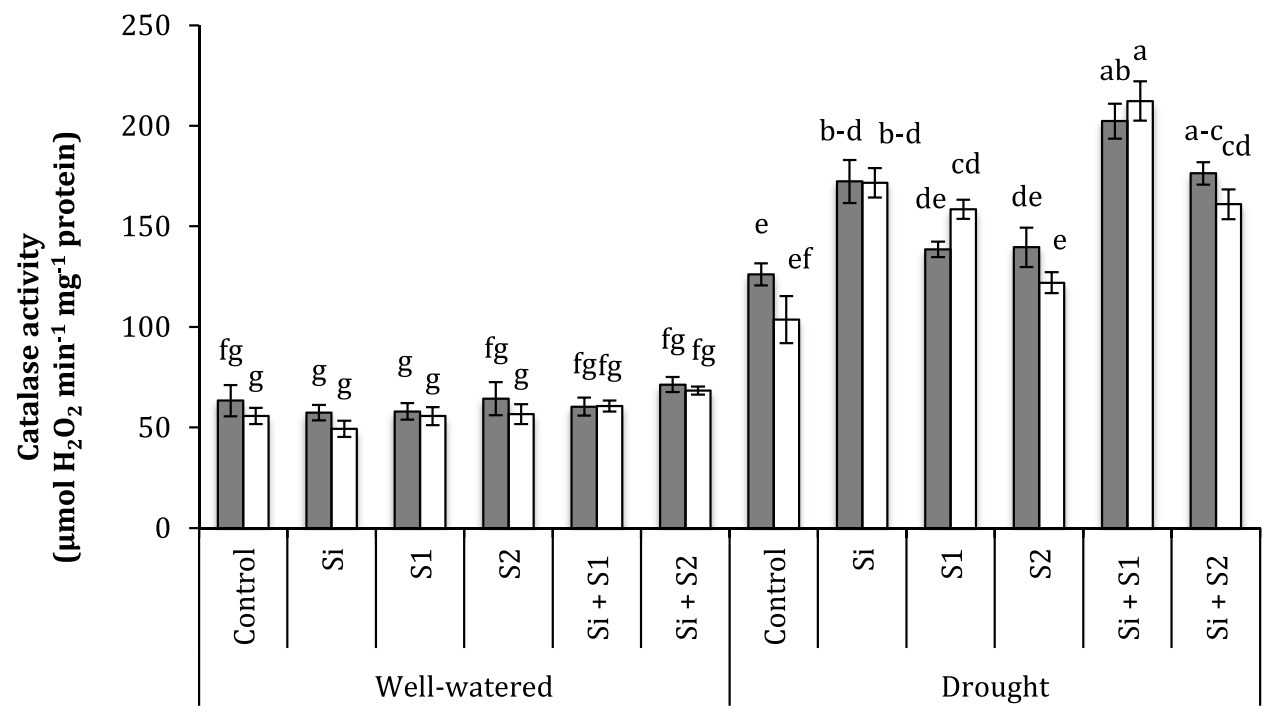

Treatments

b.

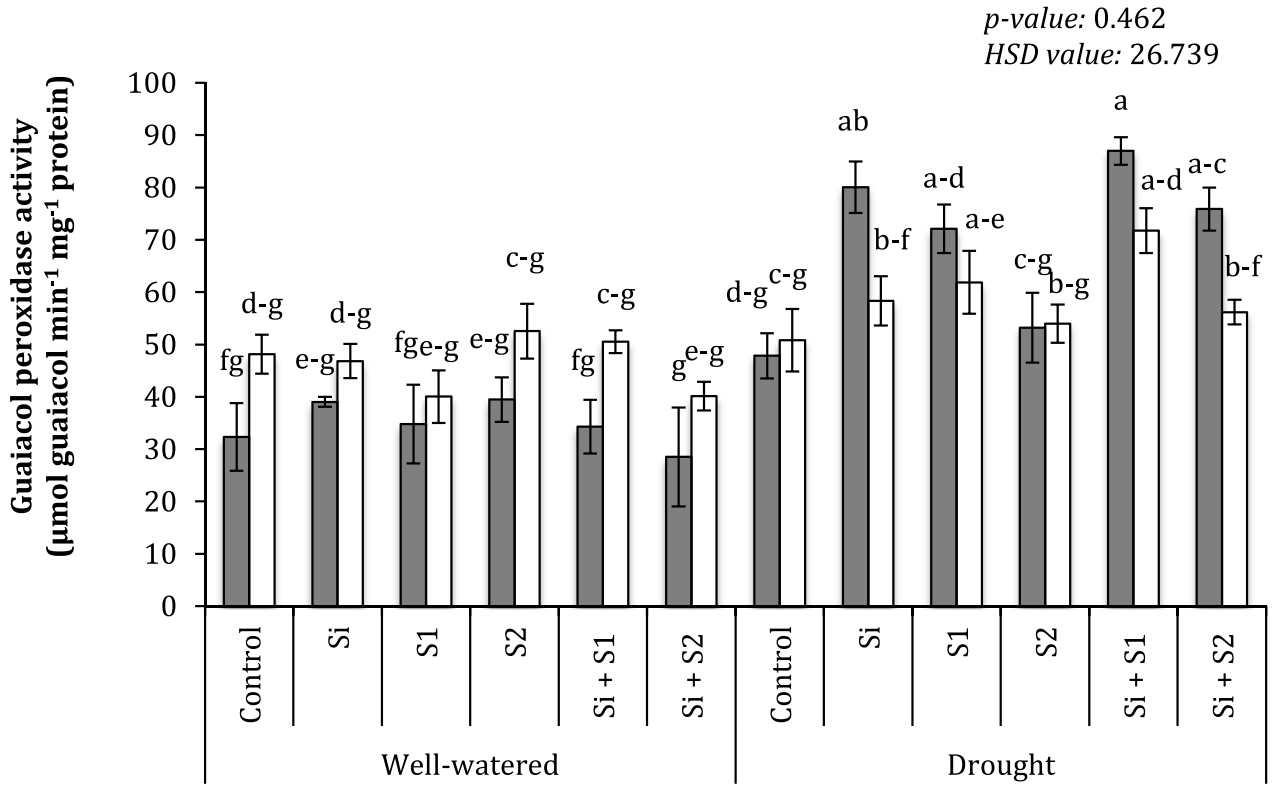

Treatments

Fig. 3 Effects of Si seed priming and foliar spray of $\mathrm{S}\left(\mathrm{S}_{1}: 0.5 \%, \mathrm{~S}_{2}: 1 \%\right)$ on (a) catalase (CAT), (b) guiaicol peroxidase (GPX) and (c) superoxide dismutase (SOD) activity of well-watered and drought stressed maize seedlings. The error bars represent variability among different treatment means and were calculated by dividing standard deviation with the square root of number of replicates $(\mathrm{n}=3)$. Different alphabets show significant differences $(p \leq 0.05)$ amongst various treatments, according to Tukey's HSD test 
c.

p-value: 0.024

HSD value: 14.903

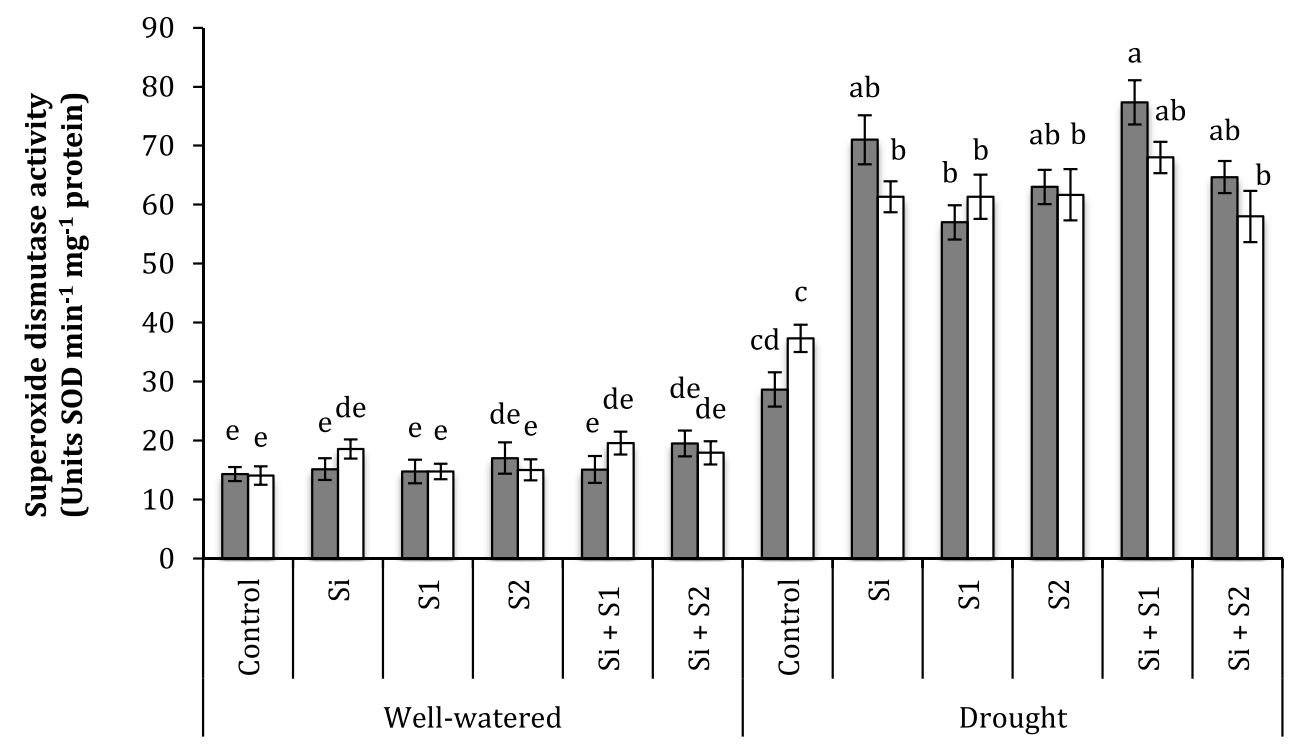

Treatments

Fig. 3 (continued)

spray of S, individually or combined, significantly ameliorated the damaging effects of drought on maize growth (Table 1). Both Si and S applications are known to mediate physiological and biochemical processes to improve biomass accumulation in plants $[29,48]$. Accordingly, in this study, the Si and S induced increment in growth attributes was found associated to the regulation of leaf water status (Fig. 1d), photosynthetic pigments (Fig. 1a-c) and stimulation of antioxidant machinery (Fig. 3a, b and c) under water deficit conditions. The higher biomass accumulation by the combined Si and S application suggests the synergistic interactions of these nutrients to enhance drought tolerance in maize. It may be inferred that foliar spray of $\mathrm{S}$ regulated the metabolic pathways to further facilitate the beneficial effects of $\mathrm{Si}$ seed priming on germinating seeds and seedling development. Hameed et al. [49] suggested that Si seed priming increases the concentrations of proteins in germinating seeds that provide energy and amino acids to counteract the deleterious effects of drought stress. Similarly, S-derived metabolites are important constituents of proteins and amino acids required for chlorophyll biosynthesis to enhance photochemical efficiency and photosynthetic activity [50], consequently increasing biomass production.

Biosynthesis and preservation of photosynthetic pigments is a potential predictor of drought tolerance in plants [51]. The present study demonstrated that drought stress negatively affected the chloroplast pigments of maize and caused a marked reduction in $\mathrm{Chl}_{\mathrm{a}}, \mathrm{Chl}_{\mathrm{b}}, \mathrm{CAR}$ with respect to well-watered conditions (Fig. 1a, b and c). Drought-induced reduction in
$\mathrm{Chl}_{\mathrm{a}}$ and $\mathrm{Chl}_{\mathrm{b}}$ might be associated with the decrease in concentrations of cysteine and methionine, which are major constituents of chloroplast target proteins [52]. Also, limited water supply stimulates oxidative damage or overproduction of ROS that reduces chlorophyll content due to photo-oxidative damage to pigments [53]. Exogenous supply of Si and S considerably reduced the damage to photosynthetic pigments and markedly increased the $\mathrm{Chl}_{\mathrm{a}}, \mathrm{Chl}_{\mathrm{b}}$ and CAR content in leaf tissues under water deficit conditions (Fig. 1a, b and c). Our findings are concurrent with the previous reports of Maghsoudi et al. [54] in wheat and Usmani et al. [29] in maize. Dehghanipoodeh et al. [55] suggested that the beneficial effects of Si are associated to the upregulation of antioxidant enzymes (also observed in the present study, Fig. 3a, b and c) that reduce lipid peroxidation and protect chloroplast structure to maintain photosynthetic pigments under water limitations. Similarly, S application prevents chlorosis in young leaves and inhibits the destruction of functional chloroplasts by reducing ROS especially $\mathrm{H}_{2} \mathrm{O}_{2}$ concentration in water stressed plants $[27,56]$. It was evident from our results that the combined $\mathrm{Si}+\mathrm{S}$ application further promoted the synthesis of chloroplast pigments, which helped to maintain higher photosynthetic activity (Fig. 2a, b, c and d) under water deficit conditions.

Water deficiency restricts the uptake of water and nutrients due to less availability of water in soil (drought), resulting in reduced plant water status and disruption of metabolic processes involved in plant growth [57]. Leaf RWC is an 
important indicator of plant water status and is significantly reduced under water deficit stress [58]. In the present study, the exogenous supply of $\mathrm{Si}$ and $\mathrm{S}$ considerably ameliorated the drought mediated decrease in leaf RWC (Fig. 1d). The beneficial effects of $\mathrm{Si}$ and $\mathrm{S}$ on plant water status have been extensively reported in various crop species [59-61]. Si availability in the xylem and leaves improves the osmotic potential of epidermis cells to increase leaf water potential under dry conditions [62]. Moreover, Si nutrition improves plant water retention by decreasing leaf transpiration and regulating water

a.

$\square$ Hi-Corn $11 \quad \square \mathrm{P}-1574$

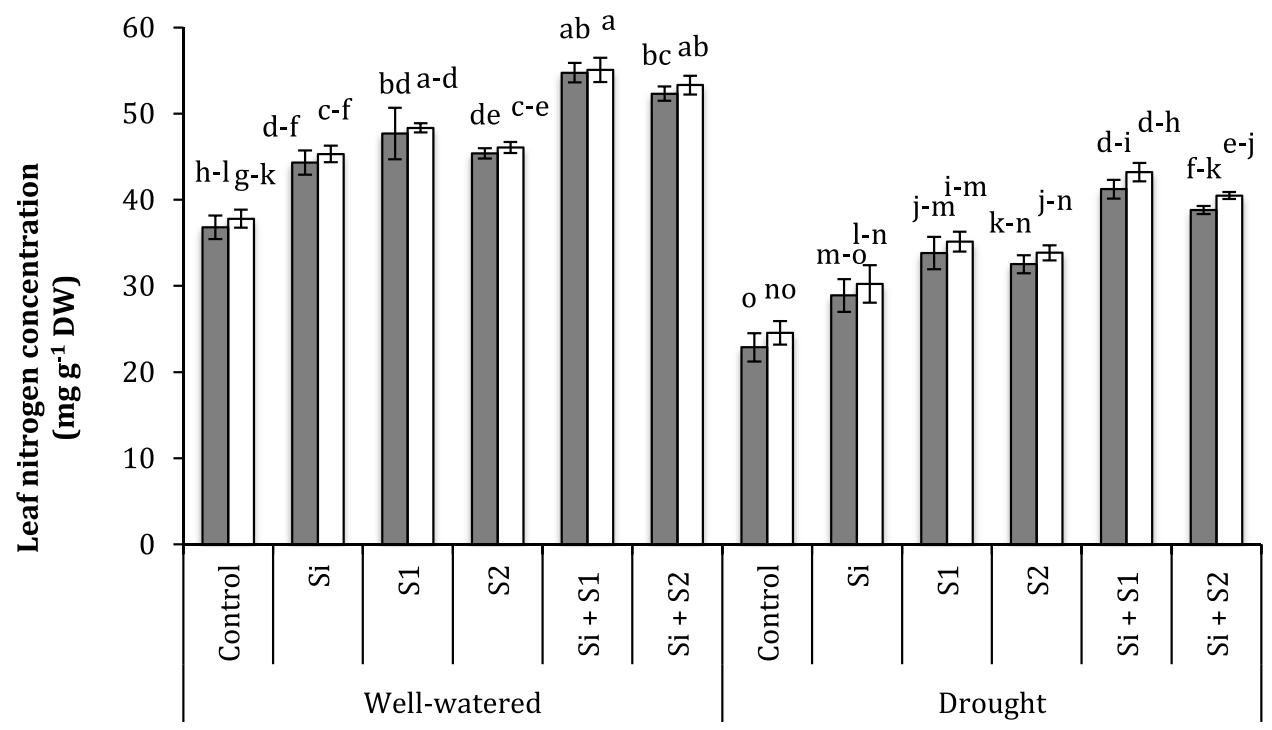

Treatments

b.

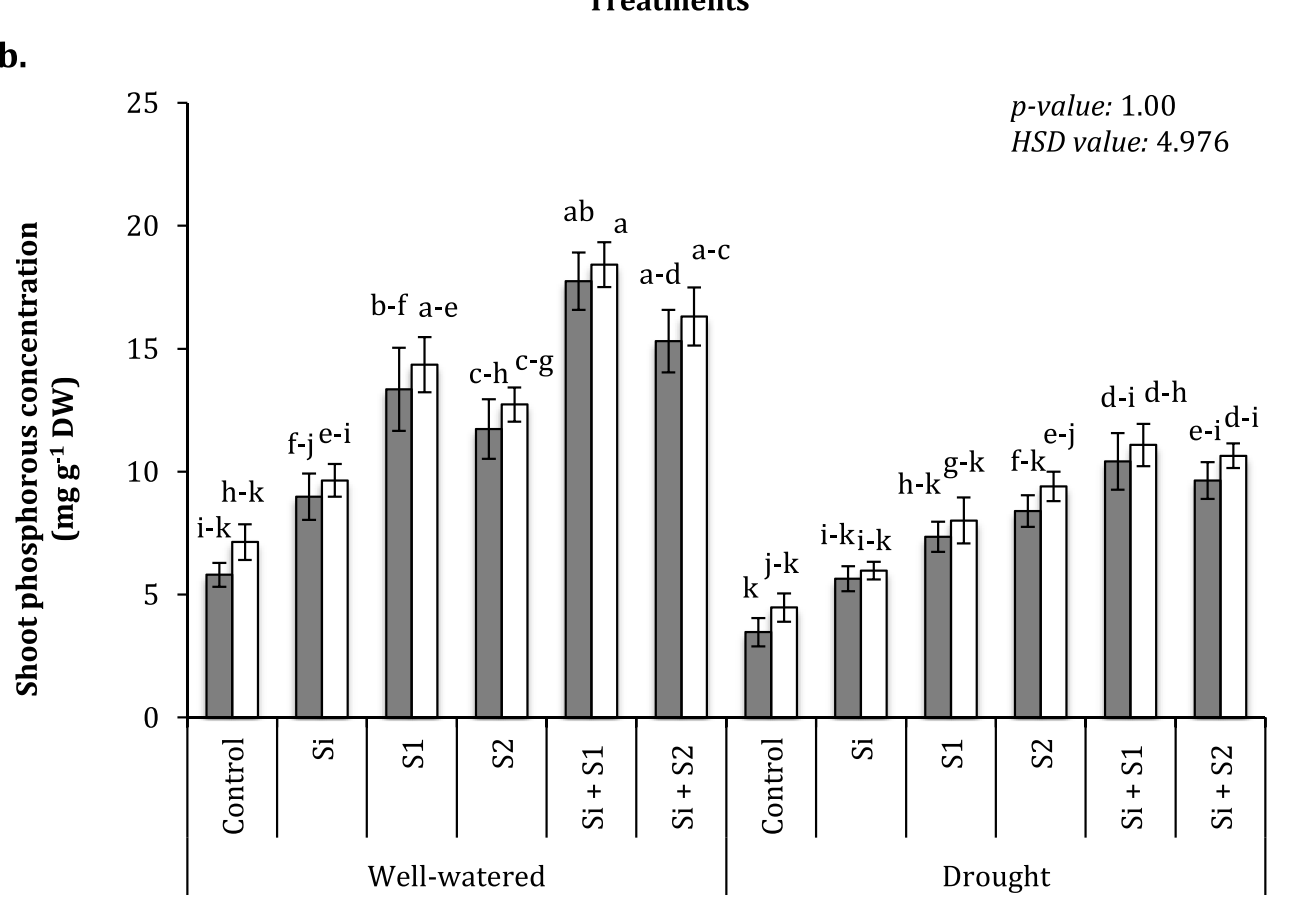

p-value: 0.999

HSD value: 7.388

Treatments

Fig. 4 Effects of Si seed priming and foliar spray of $\mathrm{S}\left(\mathrm{S}_{1}: 0.5 \%, \mathrm{~S}_{2}: 1 \%\right)$ on (a) nitrogen $(\mathrm{N})$, (b) phosphorus $(\mathrm{P})$ and (c) potassium $(\mathrm{K})$ content of well-watered and drought stressed maize seedlings. The error bars represent variability among different treatment means and were calculated by dividing standard deviation with the square root of number of replicates $(n=3)$. Different alphabets show significant differences $(p \leq 0.05)$ amongst various treatments, according to Tukey's HSD test 
c.

p-value: 0.981

HSD value: 9.854

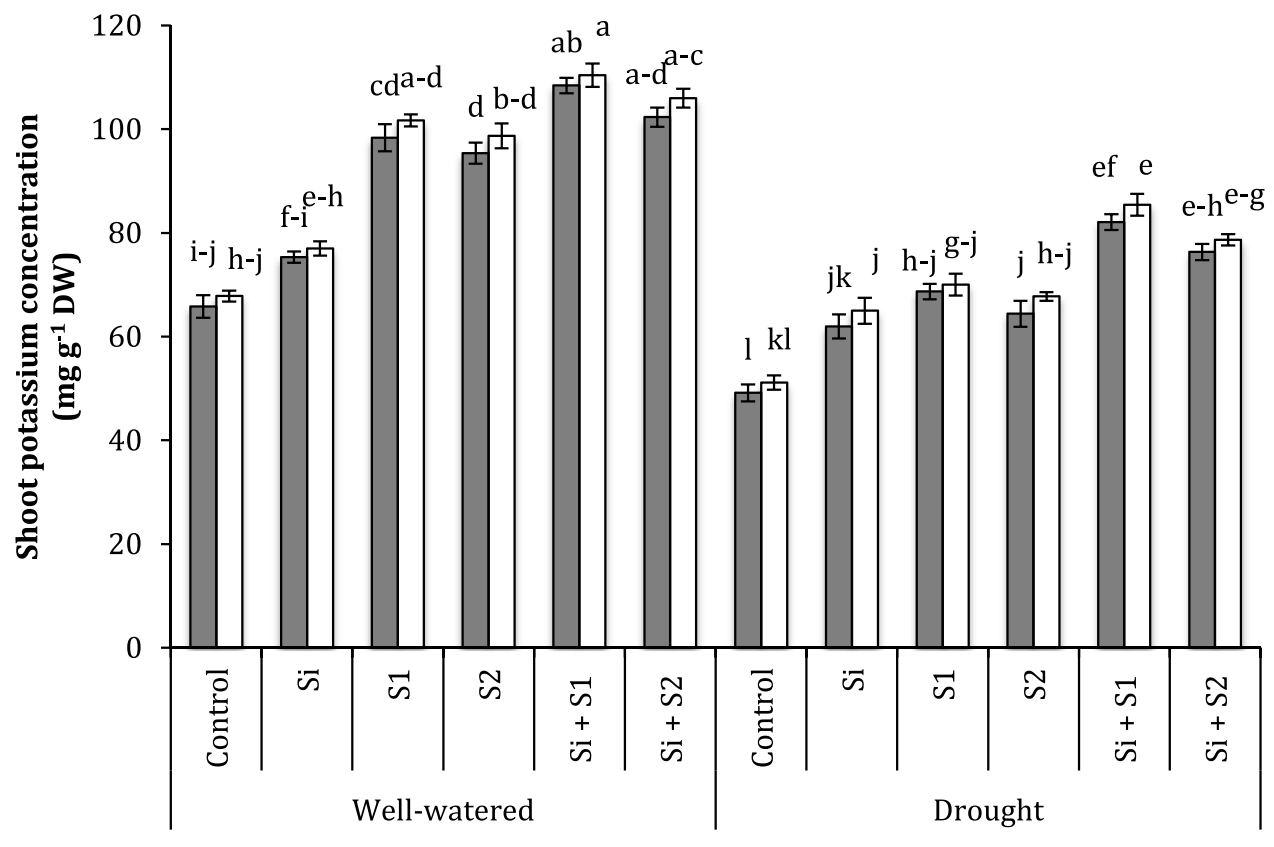

Treatments

Fig. 4 (continued)

use efficiency under drought stress [63]. Also, Si increases the hydraulic conductance of roots and promotes osmolyte accumulation to adjust osmotic potential of cells under drought stress [19]. Similarly, S plays an important role in improving the osmotic adjustment and leaf water potential of plants during stressful environments [64]. Application of $\mathrm{S}$ balances the ATP binding cassette transporters into guard cells to induce stomatal closure under drought stress [65]. Hence, Si seed priming combined with S spray assists in the regulation of plant water status by promoting water uptake, increasing osmotic adjustment and decreasing transpiration under water deficit conditions $[66,67]$.

Decrease in leaf gas exchange characteristics viz. $A, E, g s$ and $C_{i}$ is generally considered to be the prime effect of drought due to decomposition of chlorophyll and restriction of available $\mathrm{CO}_{2}[68,69]$. As expected, water deficit conditions considerably $(P \leq 0.01)$ reduced the photosynthetic efficiency of maize plants (Fig. 2a, b, c and d). Low water availability reduces $A$ by decreasing efficiency of PS-II electron transport chain in maize [70]. Under limited water supply, maize plants close their stomata (96-98\%) to save water [71] that leads to less $A$ [72]. The observed increment in leaf $A$ by Si seed priming ( $3 \mathrm{mM}$ ) combined with $\mathrm{S}$ supply (Fig. 2a) might be related to increase in photosynthesis pigments and leaf RWC, leading to higher activity of photosynthesis system [73]. The use of Si affects water transport and prevents oxidative damage to increase photosynthetic activity in water deficit plants [74]. Similarly, S fertilization influences stomatal regulation and increases the stability of Fe-S clusters to improve the performance of key cellular processes such as photosynthesis and respiration under water deficit conditions [75]. In the present study, drought mediated stomatal closure considerably decreased the $E, g_{s}$ and $C_{i}$ of maize hybrids (Fig. $2 \mathrm{~b}$ ), also reported by Romdhane et al. [76]. However, a significant increase in these attributes was observed by the exogenous application of Si and S under drought stress (Fig. 2b). These results imply that $\mathrm{Si}$ and $\mathrm{S}$ nutrition increase the hydraulic conductivity of roots and assist in metabolic processes, leading to higher gas exchange activity under water limitations [77]. Ming et al. [78] showed that Si application considerably increased the $E$ of rice plants experiencing drought. Si supply improves the regulation of aquaporins associated with hydraulic conductance of roots, resulting in higher $E$ and $g_{s}$ under drought stress [79]. Pang et al. [80] suggested that $\mathrm{Si}$ mediated increase in gas exchange characteristics is linked to the synthesis of compatible solutes under limiter water conditions. Likewise, adequate amount of S favors the synthesis of S-containing amino acids and alleviates oxidative stress to protect Rubisco and thylakoid membrane proteins under drought stress [81].

Water deficit conditions stimulate oxidative damage and lead to excessive generation of ROS in plant tissues. Plants 
use antioxidant enzymes to scavenge stress-induced ROS and the upregulation of these enzymes is considered a major stress-responsive strategy to counteract excessive ROS [82]. The exogenous $\mathrm{Si}$ and $\mathrm{S}$ applications have been known to stimulate antioxidant machinery in plants under water limitations [21, 83]. SOD alleviates cellular damage by catalyzing the dismutation of $\mathrm{H}^{+}$and superoxide radicals $\left(\mathrm{O}_{2}{ }^{-}\right)$into hydrogen peroxide $\left(\mathrm{H}_{2} \mathrm{O}_{2}\right)$, whereas CAT and GPX are responsible for demolition of $\mathrm{H}_{2} \mathrm{O}_{2}$ into water $[84,85]$. In accordance with our findings, Si seed priming was observed to upregulate CAT, POX and SOD activities in wheat, thereby reducing drought-induced oxidative damage at early growth stage [35]. Use of $\mathrm{Si}$ as a priming agent can activate antioxidant enzymes to reduce $\mathrm{O}_{2}{ }^{-}$and malondialdehyde (MDA) concentrations, which decreases the lipid peroxidation and improves membrane permeability under water deficit stress [49]. Similarly, $\mathrm{S}$ is involved in various signaling mechanisms in plants and provides additional protection against different stresses by inducing antioxidant system at gene and protein level [86]. For example, the MDA and $\mathrm{H}_{2} \mathrm{O}_{2}$ accumulation in wheat seedlings decreases by the exogenous application of $\mathrm{S}$ [87]. Hence, based on our findings, we speculate that the combined application of $\mathrm{Si}$ and $\mathrm{S}$ results in higher ROSscavenging enzyme activities than that of control or their individual application.

It was observed that limited water supply significantly $(p \leq 0.001)$ reduced $\mathrm{N}, \mathrm{P}$ and $\mathrm{K}$ concentrations in the shoots of maize plants (data presented as Suppl. Table S1). Low water availability reduces $E$, which inhibits the accumulation of nutrient like $\mathrm{N}, \mathrm{P}$ and $\mathrm{K}$ in shoots by reducing the power of roots to uptake nutrients [88]. However, Si seed priming $(3 \mathrm{mM})$ combined with foliar spray of S markedly $(p \leq 0.001)$ increased the shoot NPK concentrations under drought stress. Si improves plant water status and help in alleviating the $\mathrm{K}$ deficiency [89]. Similar responses of maize to $\mathrm{Si}$ in seedling stage were established by Shedeed [90], who reported that $\mathrm{Si}$ nutrition markedly increased N (11.9\%), P (1.62\%) and K $(53.5 \%)$ concentrations under water deficit conditions. The results of Kostic et al. [91] showed that Si promotes P uptake, whereas Chen et al. [92] concluded that Si application mediates $\mathrm{K}$ accumulation in shoots of plants exposed to stress conditions. A recent study by Zhang et al. [93] showed that $\mathrm{Si}$ application increases the concentration of different mineral elements including $\mathrm{K}$ by enhancing osmoregulatory substances and antioxidant activity in plant tissues. In another study, Si availability was observed to increase nitrogen use efficiency and harvest index in rice [94]. Recently, Hameed et al. [49] stated that Si seed priming provides energy and nutrients to induce drought tolerance in wheat. Likewise, exogenous $\mathrm{S}$ application was reported to enhance NPK concentrations in shoots of water stressed maize seedlings [29].

\section{Conclusion}

In conclusion, our results imply that Si seed priming combined with foliar spray of S could be the best solution for induction of drought tolerance in maize. The combined exogenous application of these nutrients modulated the protection of cellular structures, as demonstrated by the increase in chloroplast pigments and elevated activities of antioxidant enzymes in water stressed plants. This helped the plants to relieve oxidative damage and favored a high biomass production, which was due to the increased availability of nutrients and better performance of photosynthetic apparatus under water limitations.

Supplementary Information The online version contains supplementary material available at https://doi.org/10.1007/s12633-021-01505-6.

Acknowledgements The postdoctoral fellowship to Dr. Fahim Nawaz by Alexander von Humboldt (AvH) Foundation, Germany significantly contributed to successfully perform analytical work related to this study and is gratefully acknowledged.

Availability of Data and Materials The above-mentioned authors have all the relevant data associated with this research work and will be dedicated to share that, if will be asked to do so in future.

Author Contributions FN wrote the manuscript and designed the experiments, HMRJ conceived and designed the analyses, MF performed experimental work including laboratory analyses related to the study, MA, MAB and MBH supervised the experimental work, MAS, KSA and SM provided the reagents and assisted in statistical analysis, MA assisted in experimental work.

Funding Open Access funding enabled and organized by Projekt DEAL.

\section{Declarations}

Conflict of Interest The authors declare no conflict of interest related to this study.

Ethics Approval Not applicable (The results of this study do not involve any human or animal).

Consent to Participate Not applicable (The results of this study do not involve any human or animal).

Consent for Publication Not applicable (The results of this study do not involve any human or animal).

Open Access This article is licensed under a Creative Commons Attribution 4.0 International License, which permits use, sharing, adaptation, distribution and reproduction in any medium or format, as long as you give appropriate credit to the original author(s) and the source, provide a link to the Creative Commons licence, and indicate if changes were made. The images or other third party material in this article are included in the article's Creative Commons licence, unless indicated otherwise in a credit line to the material. If material is not included in the article's Creative Commons licence and your intended use is not permitted by statutory regulation or exceeds the permitted use, you will need to obtain 
permission directly from the copyright holder. To view a copy of this licence, visit http://creativecommons.org/licenses/by/4.0/.

\section{References}

1. Lobell DB, Roberts MJ, Schlenker W, Braun N, Little BB, Rejesus RM, Hammer GL (2014) Greater sensitivity to drought accompanies maize yield increase in the US. Midwest Sci 344:516-519

2. Holman IP, Hess TM, Rey D, Knox JW (2021) A multi-level framework for adaptation to drought within temperate agriculture. Front Environ Sci 8:282. https://doi.org/10.3389/fenvs.2020. 589871

3. Haro-Monteagudo D, Knox JW, Holman IP (2019) D-risk: a decision-support webtool for improving drought risk management in irrigated agriculture. Comput Electron Agric 162:855-858

4. Ort DR, Long SP (2014) Limits on yields in the corn belt. Science 344:484-485

5. Li Y, Guan K, Schnitkey GD, DeLucia E, Peng B (2019) Excessive rainfall leads to maize yield loss of a comparable magnitude to extreme drought in the United States. Global Change Bio 25: 2325-2337

6. Majeed S, Nawaz F, Naeem M, Ashraf MY, Ejaz S, Ahmad KS, Tauseef S, Farid G, Khalid I, Mehmood K (2020) Nitric oxide regulates water status and associated enzymatic pathways to inhibit nutrients imbalance in maize (Zea mays L.) under drought stress. Plant Physiol Biochem 155:147-160

7. Sehgal A, Sita K, Siddique KH, Kumar R, Bhogireddy S, Varshney RK, HanumanthaRao B, Nair RM, Prasad PV, Nayyar H (2018) Drought or/and heat-stress effects on seed filling in food crops: impacts on functional biochemistry, seed yields, and nutritional quality. Front Plant Sci 9:1705

8. Chanjuan L (2016) Genetically modified crops with drought tolerance: achievements, challenges, and perspectives. Springer, Geneva, pp 531-547

9. Aurangzaib M, Ahmad Z, Jalil MI, Nawaz F, Shaheen MR, Ahmad M, Hussain A, Ejaz MK, Tabassum MA (2021) Foliar spray of silicon confers drought tolerance in wheat (Triticum aestivum L.) by enhancing Morpho-physiological and antioxidant potential. Silicon. https://doi.org/10.1007/s12633-021-01271-5

10. Nawaz F, Zulfiqar B, Ahmad KS, Majeed S, Shehzad MA, Javeed HM, Tahir MN, Ahsan M (2021) Pretreatment with selenium and zinc modulates physiological indices and antioxidant machinery to improve drought tolerance in maize (Zea mays L.). South African J Bot 138:209-216

11. Ocvirk D, Špoljarević M, Kristić M, Hancock JT, Teklić T, Lisjak M (2021) The effects of seed priming with sodium hydrosulphide on drought tolerance of sunflower (Helianthus annuus L.) in germination and early growth. Ann Appl Biol 178:400-413

12. Balestrini R, Chitarra W, Antoniou C, Ruocco M, Fotopoulos V (2018) Improvement of plant performance under water deficit with the employment of biological and chemical priming agents. The $\mathrm{J}$ Agric Sci 156:680-688

13. Marthandan V, Geetha R, Kumutha K, Renganathan VG, Karthikeyan A, Ramalingam J (2020) Seed priming: a feasible strategy to enhance drought tolerance in crop plants. Int J Mol Sci 21:8258

14. da Silva Folli-Pereira M, Ramos AC, Canton GC, da Conceição JM, de Souza SB, Cogo AJ, Figueira FF, Eutrópio FJ, Rasool N (2016) Foliar application of trace elements in alleviating drought stress. Water Stress Crop Plants: A Sustainable Approach 2:669681

15. Hussain RA, Ahmad R, Nawaz F, Ashraf MY, Waraich EA (2016) Foliar NK application mitigates drought effects in sunflower (Helianthus annuus L.). Acta Physiol Plant 38:83
16. Shehzad MA, Nawaz F, Ahmad F, Ahmad N, Masood S (2020) Protective effect of potassium and chitosan supply on growth, physiological processes and antioxidative machinery in sunflower (Helianthus annuus L.) under drought stress. Ecotoxicol Environ Saf 187:109841

17. Hussain S, Mumtaz M, Manzoor S, Shuxian L, Ahmed I, Skalicky M, Brestic M, Rastogi A, Ulhassan M, Shafiq I, Allakhverdiev SI, Khurshid H, Yang W, Liu W (2021) Foliar application of silicon improves growth of soybean by enhancing carbon metabolism under shading conditions. Plant Physiol Biochem 159:43-52

18. Khan I, Awan SA, Rizwan M, Ali S, Hassan MJ, Brestic M, Zhang X, Huang L (2021) Effects of silicon on heavy metal uptake at the soil-plant interphase: a review. Ecotoxicol Environ Saf 222:112510

19. Shi Y, Zhang Y, Han W, Feng R, Hu Y, Guo J, Gong H (2016) Silicon enhances water stress tolerance by improving root hydraulic conductance in Solanum lycopersicum L. Front Plant Sci 7:196

20. Avila RG, Magalhães PC, da Silva EM, Gomes Júnior CC, de Paula Lana UG, de Alvarenga AA, de Souza TC (2020) Silicon supplementation improves tolerance to water deficiency in sorghum plants by increasing root system growth and improving photosynthesis. Silicon 12:2545-2554

21. Coskun D, Britto DT, Huynh WQ, Kronzucker HJ (2016) The role of silicon in higher plants under salinity and drought stress. Front Plant Sci 7:1072

22. Guerriero G, Hausman JF, Legay S (2016) Silicon and the plant extracellular matrix. Front Plant Sci 7:463

23. Hasan SA, Rabei SH, Nada RM, Abogadallah GM (2017) Water use efficiency in the drought-stressed sorghum and maize in relation to expression of aquaporin genes. Biol Plant 61:127-137

24. Khan I, Raza MA, Awan SA, Shah GA, Rizwan M, Ali B, Tariq R, Hassan MJ, Alyemeni MN, Brestic M, Zhang X, Ali S, Huang L (2020) Amelioration of salt induced toxicity in pearl millet by seed priming with silver nanoparticles (AgNPs): the oxidative damage, antioxidant enzymes and ions uptake are major determinants of salt tolerant capacity. Plant Physiol Biochem 156:221-232

25. Rastogi A, Tripathi DK, Yadav S, Chauhan DK, Živčák M, Ghorbanpour M, El-Sheery NI, Brestic M (2019) Application of silicon nanoparticles in agriculture. 3. Biotech 9:90

26. Chowdhury MA, Sultana T, Rahman MA, Saha BK, Chowdhury T, Tarafder S (2020) Sulphur fertilization enhanced yield, its uptake, use efciency and economic returns of Aloe vera L. Heliyon 6: e05726

27. Shafiq BA, Nawaz F, Majeed S, Aurangzaib M, Al Mamun A, Ahsan M, Ahmad KS, Shehzad MA, Ali M, Hashim S, ul Haq T (2021) Sulfate-based fertilizers regulate nutrient uptake, photosynthetic gas exchange, and enzymatic antioxidants to increase sunflower growth and yield under drought stress. J Soil Sci Plant Nutr 21:2229-2241

28. Ernst L, Goodger JQ, Alvarez S, Marsh EL, Berla B, Lockhart E, Jung J, Li P, Bohnert HJ, Chachtman DP (2010) Sulphate as a xylem-borne chemical signal precedes the expression of ABA biosynthetic genes in maize roots. J Exp Bot 61:3395-3405

29. Usmani MM, Nawaz F, Majeed S, Shehzad MA, Ahmad KS, Akhtar G, Aqib M, Shabbir RN (2020) Sulfate-mediated drought tolerance in maize involves regulation at physiological and biochemical levels. Sci Rep 10:1-13

30. Ali N, Schwarzenberg A, Yvin JC, Hosseini SA (2018) Regulatory role of silicon in mediating differential stress tolerance responses in two contrasting tomato genotypes under osmotic stress. Front Plant Sci 9:1475

31. Maillard A, Ali N, Schwarzenberg A, Jamois F, Yvin JC, Hosseini SA (2018) Silicon transcriptionally regulates sulfur and ABA metabolism and delays leaf senescence in barley under combined sulfur deficiency and osmotic stress. Environ Exp Bot 155:394-410. https://doi.org/10.1016/j.envexpbot.2018.07.026 
32. Hussain M, Bashir W, Farooq S, Rehim A (2013) Root development, allometry and productivity of maize hybrids under terminal drought sown by varying method. Int J Agric Biol 1:15

33. Majeed S, Nawaz F, Naeem M, Ashraf MY (2018) Effect of exogenous nitric oxide on sulfur and nitrate assimilation pathway enzymes in maize (Zea mays L.) under drought stress. Acta Physiol Plant 40:206

34. Jackson ML, Barak P (2005) Soil chemical analysis: advanced course. UW-Madison Libraries Parallel Press, Madison

35. Bukhari MA, Ashraf MY, Ahmad R, Waraich EA, Hameed M (2015) Improving drought tolerance potential in wheat (Triticum aestivum L.) through exogenous silicon supply. Pak J Bot 47: 1641-1648

36. Arbeitsgruppe Boden (1994) Bodenkundliche Kartieranleitung mit 33 Abbildungen und 91 Tabellen, 4. Auflage, Nachdruck 1996. Herausgegeben von der Bundesanstalt fur Geowissenschaften und Rohstoffe und den Geologischen Landesämtern in der Bundesrepublik Deutschland, Hannover, Germany

37. Arnon DI (1949) Copper enzymes in isolated chloroplasts. Polyphenoloxidase in Beta vulgaris. Plant Physiol 24:1-15

38. Mayak S, Tirosh T, Glick BR (2004) Plants growth promoting bacteria that confer resistance in tomato and pepper plants to salt stress. Plant Physiol Biochem 42:565-572

39. Chance B, Maehly C (1955) Assay of catalase and peroxidases. Methods Enzymol 2:764-775

40. Urbanek H, Kuzniak-Gebarowska E, Herka K (1991) Elicitation of defence responses in bean leaves by Botrytis cinerea polygalacturonase. Acta Physiol Plant 13:43-50

41. Van Rossum MWPC, Alberda M, van der Plas LHW (1997) Role of oxidative damage in tulip bulb scale micro propagation. Plant Sci 130:207-216

42. Wolf B (1982) A comprehensive system of leaf analyses and its use for diagnosing crop nutrient status. Commun Soil Sci Plant Anal 13:1035-1059

43. Neu S, Schaller J, Dudel EG (2017) Silicon availability modifies nutrient use efficiency and content, C:N:P stoichiometry, and productivity of winter wheat (Triticum aestivum L.). Sci Rep 7:40829. https://doi.org/10.1038/srep40829

44. Ma D, Sun D, Wang C, Qin H, Ding H, Li Y, Guo T (2016) Silicon application alleviates drought stress in wheat through transcriptional regulation of multiple antioxidant defense pathways. J Plant Growth Regul 35:1-10

45. Buchelt AC, Teixeira GCM, Oliveira KS, Rocha AMS, de Mello PR, Caione G (2020) Silicon contribution via nutrient solution in forage plants to mitigate nitrogen, potassium, calcium, magnesium, and sulfur deficiency. J Plant Nutr Soil Sci 20:1532-1548

46. Réthoré E, Ali N, Yvin JC, Hosseini SA (2020) Silicon regulates source to sink metabolic homeostasis and promotes growth of rice plants under sulfur deficiency. Int J Mol Sci 21:3677

47. Nawaz F, Majeed S, Aqib M, Ahmad KS, Ghaffar A, Usmani MM, Shabbir RN, Shafiq BA (2020) Sulfur-mediated physiological and biochemical alterations to improve abiotic stress tolerance in food crops. InPlant ecophysiology and adaptation under climate change: mechanisms and perspectives II 2020. Springer, Singapore, $\mathrm{p}$ 415-441

48. Bukhari MA, Ahmad Z, Ashraf MY, Afzal M, Nawaz F, Nafees M, Jatoi WN, Malghani NA, Shah AN, Manan A (2020) Silicon mitigates drought stress in wheat (Triticum aestivum L.) through improving photosynthetic pigments, biochemical and yield characters. Silicon 4:1-6. https://doi.org/10.1007/s12633-020-00797-4

49. Hameed A, Farooq T, Hameed A, Sheikh MA (2021) Siliconmediated priming induces acclimation to mild water-deficit stress by altering physio-biochemical attributes in wheat plants. Front Plant Sci 12:117

50. Abadie C, Tcherkez G (2019) Plant Sulphur metabolism is stimulated by photorespiration. Commun Biol 2:379
51. Naeem M, Naeem MS, Ahmad R, Ahmad R (2017) Foliar-applied calcium induces drought stress tolerance in maize by manipulating osmolyte accumulation and antioxidative responses. Pak J Bot 49: 427-434

52. Parveen A, Liu W, Hussain S, Asghar J, Perveen XY (2019) Silicon priming regulates Morpho-physiological growth and oxidative metabolism in maize under drought stress. Plants 8:431

53. Anjum SA, Ashraf U, Tanveer M, Khan I, Hussain S, Shahzad B, Zohaib A, Abbas F, Saleem MF, Ali I (2017) Drought induced changes in growth, Osmolyte accumulation and antioxidant metabolism of three maize hybrids. Front Plant Sci 8:69

54. Maghsoudi K, Emam Y, Ashraf M (2015) Influence of foliar application of silicon on chlorophyll fluorescence, photosynthetic pigments, and growth in water-stressed wheat cultivars differing in drought tolerance. Turk J Bot 39:625-634

55. Dehghanipoodeh S, Ghobadi C, Baninasab B, Gheysari M, Bidabadi SS (2018) Effect of silicon on growth and development of strawberry under water deficit conditions. Hortic Plant J 4:226-232

56. Kaya C, S,enbayram M, Akram NA, Ashraf M, Alyemeni MN, Ahmad P (2020) Sulfur-enriched leonardite and humic acid soil amendments enhance tolerance to drought and phosphorus deficiency stress in maize (Zea mays L.). Sci Rep 14:1-3

57. Helaly MN, El-Hoseiny H, El-Sheery NI, Rastogi A, Kalaji HM (2017) Regulation and physiological role of silicon in alleviating drought stress of mango. Plant Physiol Biochem 118:31-44

58. Chowdhury JA, Karim MA, Khaliq QA, Ahmed AU, Mondol AM (2018) Effect of drought stress on water relation traits of four soybean genotypes. SAARC J Agric 15:163-175

59. Ahmed M, Asif M, Hassan F (2014) Augmenting drought tolerance in sorghum by silicon nutrition. Acta Physiol Plant 36:473-483

60. Li H, Zhu Y, Hu Y, Han W, Gong H (2015) Beneficial effects of silicon in alleviating salinity stress of tomato seedlings grown under sand culture. Acta Physiol Plant 37:71

61. Müller M, Tormena CA, Genú A, Kramer L, Michalovicz L, Caires EF (2012) Structural quality of a no-tillage red latosol 50 months after gypsum application. Rev Bras Ciênc Solo 36:1005-1014

62. Chen W, Yao XQ, Cai KZ, Chen JN (2011) Silicon alleviates drought stress of rice plants by improving plant water status, photosynthesis and mineral nutrient absorption. Biol Trace Elem Res 142:67-76

63. Tripathi, DK, Singh S, Singh S, Chauhan DK, Dubey NK, Prasad R (2016) Silicon as a beneficial element to combat the adverse effect of drought in agricultural crops. In: Ahmad (ed) Water stress and crop plants: a sustainable approach, p 682-694

64. Abuelsoud W, Hirschmann F, Papenbrock J (2016) Sulfur metabolism and drought stress tolerance in plants. Drought Stress Toler Plants 1:227-249

65. García-Mata C, Lamattina L (2010) Hydrogen sulphide, a novel gasotransmitter involved in guard cell signalling. New Phytol 188:977-984

66. Lee BR, Zaman R, Avice JC, Ourry A, Kim TH (2016) Sulfur use efficiency is a significant determinant of drought stress tolerance in relation to photosynthetic activity in Brassica napus cultivars. Front Plant Sci 7:459

67. Zhu Y, Gong H (2014) Beneficial effects of silicon on salt and drought tolerance in plants. Agron Sustain Dev 34:455-472

68. Iqbal N, Hussain S, Raza MA, Yang CQ, Safdar ME, Brestic M, Aziz A, Hayyat MS, Asghar MA, Wang XC, Zhang J, Yang W, Liu J (2019) Drought tolerance of soybean (Glycine max L. Merr.) by improved photosynthetic characteristics and an efficient antioxidant enzyme activities under a split-root system. Front Physiol 10:786

69. Min H, Chen C, Wei S, Shang X, Sun M, Xia R, Liu X, Hao D, Chen H, Xie Q (2016) Identification of drought tolerant mechanisms in maize seedlings based on transcriptome analysis of recombination inbred lines. Front Plant Sci 7:1080 
70. Zhang X, Lei L, Lai J, Zhao H, Song W (2018a) Effects of drought stress and water recovery on physiological responses and gene expression in maize seedlings. BMC Plant Biol 18:68

71. Kim SG, Lee JS, Bae HH, Kim JT, Son BY, Kim SL, Baek SB, Shin S, Jeon WT (2019) Physiological and proteomic analyses of Korean F1 maize (Zea mays L.) hybrids under water-deficit stress during flowering. App. Biol Chem 62:32

72. Zhao W, Sun Y, Kjelgren R, Liu X (2015) Response of stomatal density and bound gas exchange in leaves of maize to soil water deficit. Acta Physiol Plant 37:1704

73. Ning D, Qin A, Liu Z, Duan A, Xiao J, Zhang J, Liu Z, Zhao B, Liu $Z$ (2020) Silicon-mediated physiological and agronomic responses of maize to drought stress imposed at the vegetative and reproductive stages. Agron 10:1136

74. Zhang Y, Yu SH, Gong HJ, Zhao HL, Li HL, Hu YH, Wang YC (2018b) Beneficial effects of silicon on photosynthesis of tomato seedlings under water stress. J Integr Agric 17:2151-2159

75. Duan J, Fu B, Kang H, Song Z, Jia M, Cao D, Wei A (2019) Response of gas-exchange characteristics and chlorophyll fluorescence to acute sulfur dioxide exposure in landscape plants. Ecotoxic. Environ Safety 171:122-129

76. Romdhane L, Awad YM, Radhouane L, Dal CC, Barion G, Panozzo A, Vamerali T (2018) Wood biochar produces different rates of root growth and transpiration in two maize hybrids (Zea mays L.) under drought stress. Arch Agron Soil Sci 1:532-567

77. Abdel Latef AA, Tran LSP (2016) Impacts of priming with silicon on the growth and tolerance of maize plants to alkaline stress. Front Plant Sci 7:243

78. Ming DF, Pei ZF, Naeem MS, Gong HJ, Zhou WJ (2012) Silicon alleviates PEG-induced water-deficit stress in upland rice seedlings by enhancing osmotic adjustment. J Agron Crop Sci 198:14-26

79. Liu P, Yin L, Deng X, Wang S, Tanaka K, Zhang S (2014) Aquaporin-mediated increase in root hydraulic conductance is involved in silicon-induced improved root water uptake under osmotic stress in Sorghum bicolor L. J Exp Bot 1:4747-4756

80. Pang Z, Tayyab M, Islam W, Tarin MWK, Sarfaraz R, Naveed H, Zaman S, Zhang B, Yuan Z, Zhang H (2019) Silicon mediated improvement in tolerance of economically important crops under drought stress. Appl Ecol Environ Res 17:6151-6170

81. Chan KX, Wirtz M, Phua SY, Estavillo GM, Pogson BJ (2013) Balancing metabolites in drought: the sulfur assimilation conundrum. Trends Plant Sci 18:18-29

82. Rao DE, Chaitanya KV (2016) Photosynthesis and antioxidative defense mechanisms in deciphering drought stress tolerance of crop plants. Biol Plant 1:201-218

83. Muneer S, Lee BR, Kim KY, Park SH, Zhang Q, Kim TH (2014) Involvement of Sulphur nutrition in modulating iron deficiency responses in photosynthetic organelles of oilseed rape (Brassica napus L.). Photosynth Res 119:319-332

84. Hu KD, Bai GS, Li WJ, Yan H, Hu LY, Li YH, Zhang H (2015) Sulfur dioxide promotes germination and plays an antioxidant role in cadmium-stressed wheat seeds. Plant Growth Regul 1:271-280
85. Wang SS, Zhang YX, Yang F, Huang ZQ, Tang J, Hu KD, Zhang $H$ (2017) Sulfur dioxide alleviates programmed cell death in barley aleurone by acting as an antioxidant. PLoS One 2:12

86. Corpas FJ, Palma JM (2020) $\mathrm{H}_{2} \mathrm{~S}$ signaling in plants and applications in agriculture. J Adv Res 24:131-137

87. Li LH, Yi HL, Liu XP, Qi HX (2020) Sulfur dioxide enhance drought tolerance of wheat seedlings through $\mathrm{H}_{2} \mathrm{~S}$ signaling. Ecotoxicol Environ Saf 11:111248

88. Shabbir RN, Waraich EA, Ali H, Nawaz F, Ashraf MY, Ahmad R, Awan MI, Ahmad S, Irfan M, Hussain S, Ahmad Z (2016) Supplemental exogenous NPK application alters biochemical processes to improve yield and drought tolerance in wheat (Triticum aestivum L.). Environ Sci Pollut Res 23:2651-2662

89. Wang Y, Wu WH (2013) Potassium transport and signaling in higher plants. Annu Rev Plant Biol 64:451-476

90. Shedeed SI (2018) Assessing effect of potassium silicate consecutive application on forages maize plants (Zea. Mays. L). JIPBS 5:119-127

91. Kostic L, Nikolic N, Bosnic D, Samardzic J, Nikolic M (2017) Silicon increases phosphorus $(\mathrm{P})$ uptake by wheat under low $\mathrm{P}$ acid soil conditions. Plant Soil 419:447-455

92. Chen DQ, Cao BB, Wang SW, Liu P, Deng XP, Yin LN, Zhang SQ (2015) Silicon moderated the K deficiency by improving the plantwater status in sorghum. Sci Rep 6:22882

93. Zhang Y, Liang Y, Zhao X, Jin X, Hou L, Shi Y, Ahammed GJ (2019) Silicon compensates phosphorus deficit-induced growth inhibition by improving photosynthetic capacity, antioxidant potential, and nutrient homeostasis in tomato. Agronomy 9:733

94. Song AL, Fan FL, Yin C, Wen SL, Zhang YL, Fan XP, Liang YC (2017) The effects of silicon fertilizer on denitrification potential and associated genes abundance in paddy soil. Biol Fertil Soils 53:627-638

95. CIMMYT (1988) From agronomic data to farmer recommendations. An economics training manual. Complete revises edition. Mexico D F 1-16

96. Liang YC, Chen Q, Liu Q, Zhang WH, Ding RX (2003) Exogenous silicon $(\mathrm{Si})$ increases antioxidant enzyme activity and reduces lipid peroxidation in roots of salt-stressed barley (Hordeum vulgare L.). $\mathrm{J}$ Plant Physiol 160:1157-1164

97. Milne CJ, Laubscher CP, Ndakidemi PA, Marnewick JL, Rautenbach F (2012) Salinity induced changes in oxidative stress and antioxidant status as affected by applications of silicon in lettuce (Lactuca sativa). Int J Agric Biol 14(5):763-768

98. Saud S, Li X, Chen Y, Zhang L, Fahad S, Hussain S, Sadiq A, Chen Y (2014) Silicon application increases drought tolerance of Kentucky bluegrass by improving plant water relations and morphophysiological functions. Sci World J 2014:4-9

Publisher's Note Springer Nature remains neutral with regard to jurisdictional claims in published maps and institutional affiliations. 